\title{
Enclosing the Gold-Mining Commons of Mongolia
}

\section{The Vanishing Ninja and the Development Project as Resource}

\author{
by G. Munkherdene and David Sneath
}

Online enhancements: supplemental material

\begin{abstract}
Since its emergence in the mid-1990s, unauthorized small-scale gold mining — widely known as "ninja mining"—has grown to become a central element of Mongolia's informal economy, engaging tens of thousands of people in seasonal, unregulated, and occasionally dangerous labor. In this paper we set out to show that the story of ninja mining is illustrative of the wider transformation of political economy that Mongolia has experienced, in which a de facto public resource was created in the wake of the collapsed state socialist economy, only to be progressively privatized and enclosed by increasingly powerful mining company interests. We examine the implementation of a development project aimed at providing sustainable livelihoods for those engaged in unauthorized mining. Drawing upon anthropological critiques of development, we explore the ways in which the project, while arguably succeeding in its own terms, failed to meet the expectations of the miners involved. Committed as it was to working within the new private property regime for land introduced by "neoliberal" reforms, the project constructed the ninja "problem" in terms of a lack of formalization and training. It was ultimately unable to address the fundamental issues of property relations and access to resources that lie at the heart of the ninja phenomenon.
\end{abstract}

Since its emergence in the mid-1990s, the phenomenon of the "ninja" unauthorized artisanal gold mining of Mongolia captured considerable journalistic and scholarly attention. The spectacle of thousands of toiling people honeycombing the landscape with hand-dug pits (see figs. S1-S7, available online) led to a number of development initiatives designed to improve the working conditions and security of the miners concerned. Development assessments of ninja mining have represented it as a response to poverty, as a livelihood "safety net," and have focused upon what was conceived of as a workforce within a new, informal sector of the economy in need of formalization and regulation.

In this paper we set out to show that the story of ninja mining is illustrative of the wider transformation of political economy that Mongolia has experienced, in which a de facto public resource was created in the wake of the collapsed state socialist economy, only to be progressively privatized and enclosed by increasingly powerful mining company interests. From this

G. Munkherdene is a Lecturer in the Department of Humanities, Mongolian University of Science and Technology (Ulaanbaatar, Mongolia [gmunkherdene@gmail.com]). David Sneath is Reader and Director of the Mongolia and Inner Asia Studies Unit in the Department of Social Anthropology of the University of Cambridge (Free School Lane, Cambridge CB2 3RF, United Kingdom [ds114@cam.ac.uk]). This paper was submitted 1 III 17, accepted 22 IX 17, and electronically published 13 XII 18. perspective, ninja mining is not simply a result of precarity, poverty, and underemployment, but a response to the appearance of a new resource, one that is now rapidly shrinking in the face of legal and commercial appropriation. This new resource emerged already entangled in the unique historical and social context of the Mongolian landscape, and this is reflected in the nature of the de facto commons that it created and the resulting conflicts over access. Historically, the production of new resources has led to competition and conflict in Mongolia, particularly in the case of land, which has been subject to a succession of different property regimes. ${ }^{1}$ Paradoxically, perhaps, the reaction of development agencies to the ninja phenomenon was generative of new resources, and new sites for conflict and competition. Ultimately, however, the inability to address the fundamental issues of property relations that lay behind the ninja phenomenon made it impossible to fully address the problems they give rise to.

Mongolia's Scavenger Economy: Surviving the 1990s

In 1990 the Soviet-style party-state establishment that had governed Mongolia since the 1920s relinquished its monopoly of power and introduced a multiparty parliamentary system. With

1. Following Verdery (2003), we take "property regime" to indicate a system of property relations that "organize people with respect to one another, and to things, goods and values" (18).

(C) 2018 by The Wenner-Gren Foundation for Anthropological Research. All rights reserved. 0011-3204/2018/5906-0008\$10.00. DOI: 10.1086/700961 
the collapse of the USSR and the COMECON Soviet trading bloc, the Mongolian state leadership rushed to make the transition from a centrally planned to a market economy. Under the supervision of the IMF, the World Bank, and the Asian Development Bank (ADB), in 1991 Mongolia's neophyte free marketers launched a "shock therapy" program to rapidly establish a globally integrated free market economy, similar to that introduced by Boris Yeltsin's administration in Russia, and with similarly disastrous economic results (Goldman 2003; Griffin 1995; Nolan 1995). ${ }^{2}$ The strategy reflected neoliberal theory as Harvey (2005:2) characterized it, in which the economy should be emancipated from the political structure and allowed to assume its latent "natural" form, composed of private property and the market. ${ }^{3}$ Although in 1991 the Mongolian president Punsalmaagiin Ochirbat (1996:235-236) predicted that the country would rapidly develop another Asian Tiger economy, Mongolia experienced something more akin to development in reverse; most state-owned enterprises collapsed, and unemployment and underemployment soared. As in Russia, incomes, public services, and living standards plummeted (Griffin 1995:viii; World Bank 1994:19). The number of people living below the poverty line increased from almost none in 1989 to more than 33\% in 1998 (United Nations Systems in Mongolia 1999:5; World Bank 1994:41). As Griffin (1995:12-13) notes, the severity of the economic collapse reflected both the loss of Soviet economic aid and the way in which a new regime of private ownership was rapidly and destructively introduced. ${ }^{4}$

The country was promoted as a resource pool for global markets. Lhamsuren Munkh-Erdene (2011:65) describes the

2. From the outset, Mongolian government policy was heavily influenced by external development agencies, particularly the IMF and ADB (Griffin 1995:10; Lhamsuren Munkh-Erdene 2011:63; Rossabi 2005: 43-48).

3. Harvey (2005:2) describes neoliberalism in this sense as "a theory of political economic practices that proposes that human well-being can best be advanced by liberating individual entrepreneurial freedoms and skills within an institutional framework characterized by strong private property rights, free markets, and free trade. The role of the state is to create and preserve an institutional framework appropriate to such practices. The state has to guarantee, for example, the quality and integrity of money. It must also set up those military, defense, police, and legal structures and functions required to secure private property rights and to guarantee, by force if need be, the proper functioning of markets. Furthermore, if markets do not exist (in areas such as land, water, education, health care, social security, or environmental pollution) then they must be created, by state action if necessary. But beyond these tasks the state should not venture. State interventions in markets (once created) must be kept to a bare minimum."

4. One of the reasons for Mongolia's economic crisis was the loss of Soviet aid, which was reduced in 1989 and stopped altogether in 1991; this aid was estimated to have represented as much as $30 \%$ of gross domestic product (GDP). However, Western nations, Japan, and international financial institutions took the place of Russia as aid donors and economic advisers to some extent. Together these donors provided support that rose to represent 25\% of GDP by 1996 (Bruun and Odgaard 1996:26). new policies as the transformation of society into an adjunct to the market in which the Soviet-style regime was reincarnated as a neoliberal "night watchman" state, and parts of the Communist nomenklatura successfully reinvented themselves as an oligarchic plutocracy by acquiring ownership of the few remaining sources of large-scale wealth. Mongolia's socialist-era industrial sector was largely abandoned alongside Mongolia's socialist welfare system, which was starved of resources.

The effect was to make a large part of the national population dependent upon a kind of "scavenger economy" in which the key to realizing value was the location, appropriation, and sale of resources left over from the collapse of the state-planned economy. Scrap metal, for example, extracted from closed-down factories, railway lines, and Soviet military bases became a major sector of the economy (Byambabaatar 2016). In the capital city of Ulaanbaatar, begging street children and dusty figures collecting discarded plastic bottles became common sights. In the peri-urban districts of Ulaanbaatar and across the country it became common to see piles of scavenged materials in the household enclosures (hashaas) of the yurt (ger) or cabin dwellings that most households lived in. Even the bricks and concrete slab sections of blocks of flats made derelict by the collapse of infrastructure and services were extracted and could be seen piled up, ready for sale or reuse (fig. 1).

\section{The Rise of the Ninja}

One of the most dramatic developments of the 1990s was the appearance of "ninja" miners. These were generally small groups of people who went to areas with gold deposits and began to mine and extract gold without any official authorization. The origin of the term "ninja" is not entirely clear. The most common explanation is that when wearing the large plastic bowls used for gold panning on their backs, they resembled the TV Teenage Mutant Ninja Turtles. The association of the ninja with stealth, however, resonates with another aspect of this practice - its unauthorized or illegal nature. The term has a faintly derogatory tone, however, and most of those involved do not much like being called ninja. The development literature generally uses the term "artisanal and small-scale gold mining" (ASGM) and bichil uurhai (micro mining) in Mongolian. The practice mushroomed, and by the late 1990s, many tens of thousands of people were engaged in ninja mining.

As Humphrey (2010) noted, this "gold rush" was one of the most significant developments in the rural economy since the collapse of state socialism. In many regions, there were few pastoralist and unemployed families without at least one member working in the goldfields (High 2008; Humphrey 2010:5). The work itself is grueling and frequently dangerous; in most cases, it involves hand-digging holes several meters deep to find alluvial earth with a gold content and then laboriously hauling this to the surface where gold can be separated by panning or the use of a vibrating table (fig. 2). The holes dug in this way can be $10 \mathrm{~m}$ or more in depth; many are unsupported and liable to collapse, causing numerous fatalities (Munkherdene 2011:42-44). In 


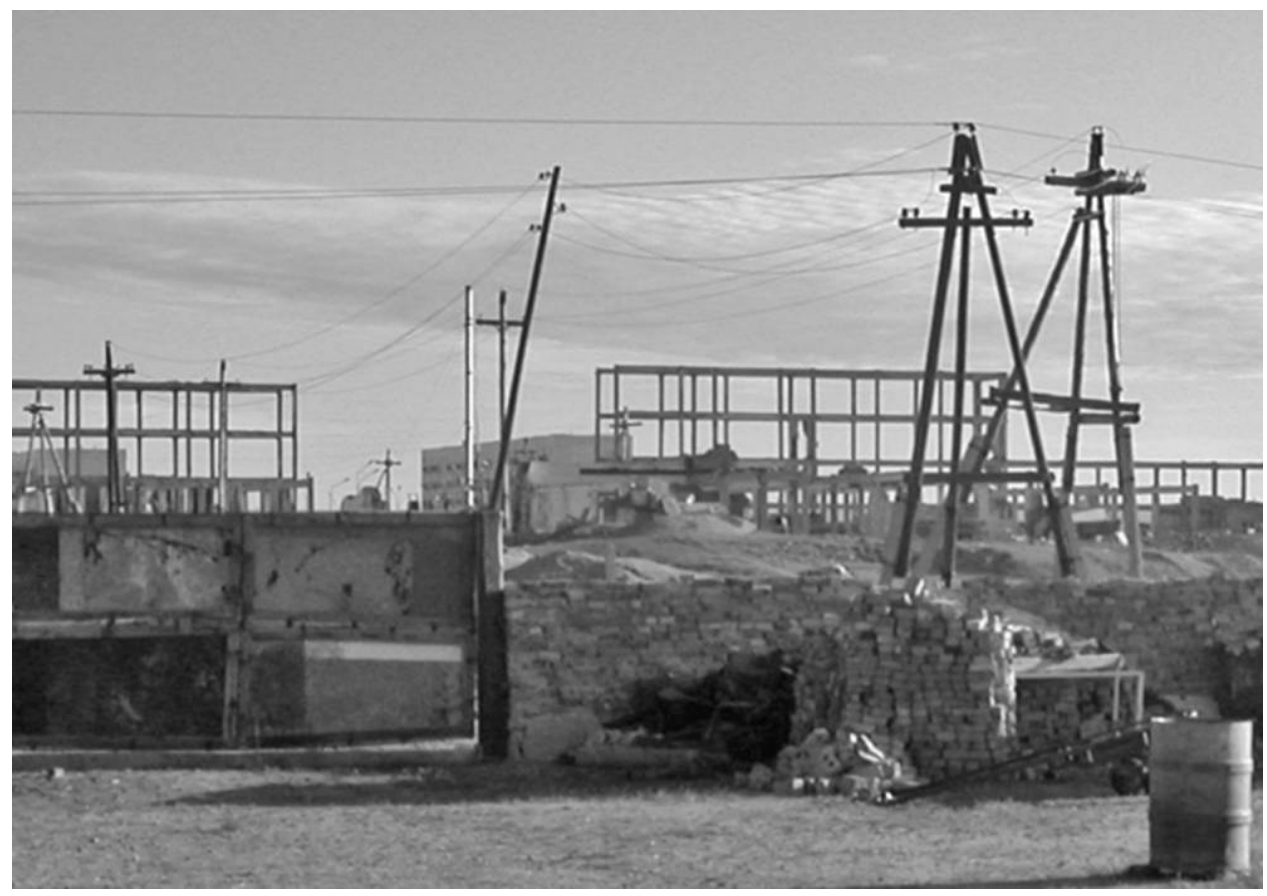

Figure 1. Salvaged building materials from derelict buildings in background. Shiveegov' Gov'sümber Province, July 2004. Photo by D. Sneath. A color version of this figure is available online.

hard-rock areas, explosives and chiseling are used to extract rock that is broken down by hammering and then milled to sand-sized particles by machine. The gold is then extracted by the use of mercury or cyanide, with all the attendant health risks (Murray and Grayson 2003:45-46).

At first glance, then, ninja mining is a classic symptom of Mongolia's "neoliberal" era and another example of globally expanding conditions of precarity. Economically disenfranchised by mass unemployment, large parts of the Mongolian public were driven literally underground to seek out precarious livelihoods in a harsh new sector of the informal economy. The inversion of the relative structural positions of the formal and informal sectors gave rise to what Davis (2004) has described as "informal survivalism" (26). ${ }^{5}$

The phenomenon attracted foreign media attention, and international development agencies quickly identified "ninja mining" as one of the most significant social problems in Mongolia (Grayson 2007:1; Murray and Grayson 2003:7; Navch et al. 2006:17; World Bank 2006:1). ${ }^{6}$ One strand in development literature emphasized the desperately harsh working conditions of unauthorized miners and the social and environmental dam-

5. As Millar (2014:49) remarks in the case of Brazil, "The figure of the unemployed worker sifting through refuse on a city dump certainly evokes what Mike Davis (2004:26) has termed 'informal survivalism.'”

6. An International Labour Organization report, for example, notes, "In recent years, an increasing number of Mongolians has turned to informal gold mining for their livelihood. This is because a number of environmental and economic factors have reduced rural income opportunities, decimated livestock herds and led to rising unemployment in age caused by the practice, particularly mercury poisoning, because the metal is widely used to extract the gold (see, e.g., Munkherdene 2011:39; UNEP 2012:4-5). Large numbers of children were involved with the work, and there was widespread concern as to the negative impact on their health and education (Navch et al. 2006). Another more influential strand emphasized the income-generating potential of the new activities. Given the need for a subsistence safety net in the face of unemployment, underemployment, and poverty, "artisanal and small-scale mining" offered a trickle of hard-earned wealth to those most in need, and it did so within a free market and at almost no cost to the state (Grayson et al. 2003:19; World Bank 2006:8). Another idea was that the practice retained "rural people" in the countryside and reduced the flow of people into the peri-urban periphery of the capital city Ulaanbaatar. A World Bank consultant, for example, noted that there were "significant advantages with a well-developed small-scale mining [sector]. It supports a large group of people and it significantly reduces the migration from rural areas to cities" (Appel 2005:10). A 2012 United Nations Environment Program report notes, for example, "ASGM ha a huge development potential in rural economies ... revenue is injected directly into local economies with local citizens directly benefiting from otherwise non-economic deposits (by LSM standards). This can only be realized when ASGM is formalized and given chance to show its socio-economic benefits" (UNEP 2012:7).

both rural and urban areas. These people see few alternatives to gold mining" (Thomas and Ganbaatar 2006:3). 


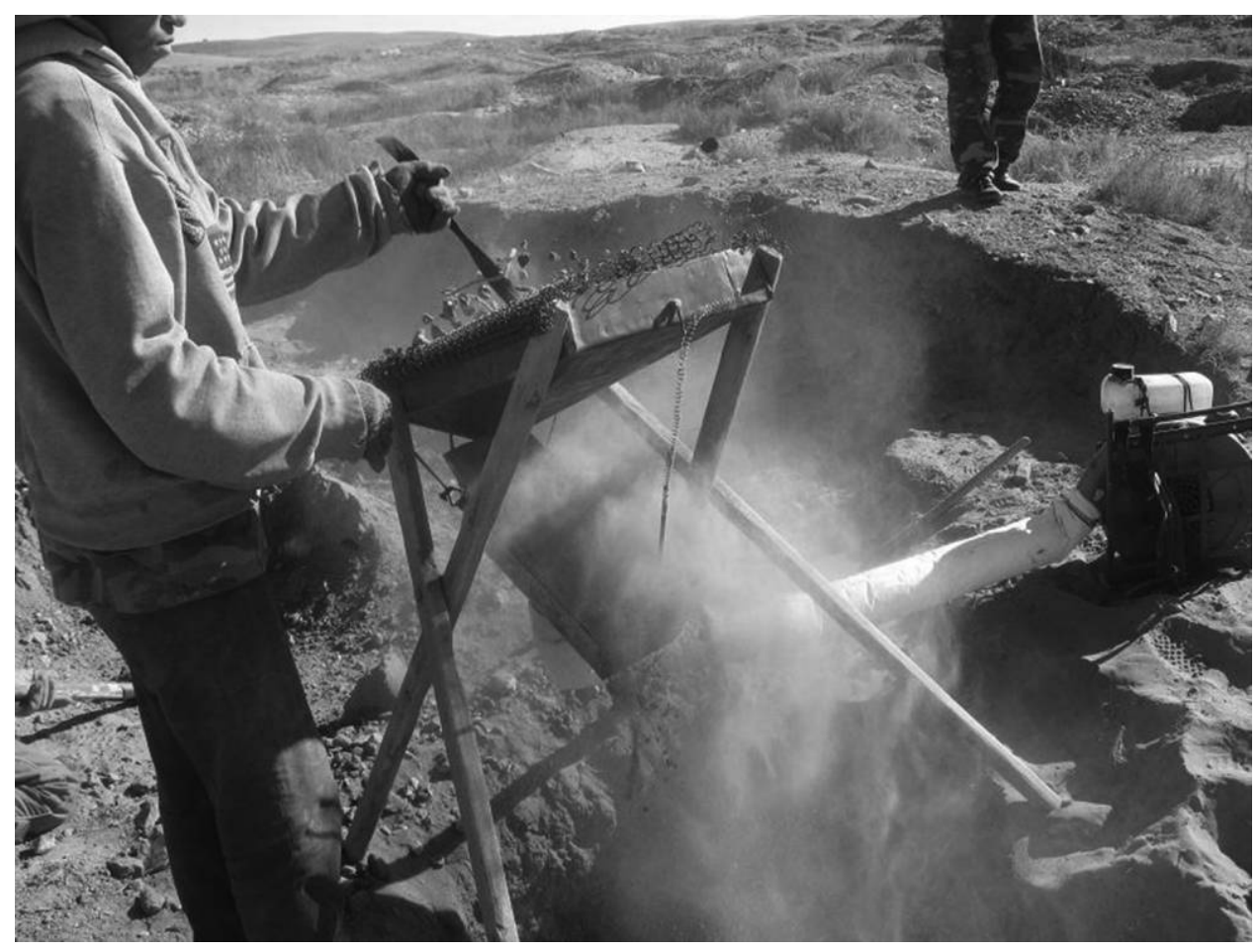

Figure 2. Sifting alluvial soil using gravitation and compressor. Zaamar, June 2013. Photo by G. Munkherdene. A color version of this figure is available online.

Mongolia's "gold rush" attracted enormous numbers of people, but estimates as to just how many remained vague. The World Bank (2006:1) estimated the number of ninja miners in the country in the early twenty-first century at between 30,000 and 100,000. Other development agencies, such as the Swiss Agency for Development and Cooperation (SDC), tend to use the higher end of this range, claiming that over 100,000 people worked in the sector in 2005 (SDC 2015:1; see Grayson et al. 2003; Murray and Grayson 2003). ${ }^{7}$ These agencies and popular press articles tend to cite the large, round number estimate of 100,000 found in other development reports (see, e.g., Knight 2007; Navch et al. 2006:17), although higher estimates also circulated; the Asia Foundation (2006), for example, reported approximately 250,000 ninja miners.

However, when the first systematic official count was carried out in 2012, the Mongolian Statistical Office (2012:15) recorded just 13,400 people working in the small-scale mining sector, little more than a tenth of the earlier estimates. How can this huge discrepancy be explained? First, the lower official figures reflect the ephemeral, fluid nature of the ninja phenomenon, which for most of those involved is a practice rather than an occupation. Many people worked in the goldfields for a few weeks or months, often in the summer, and then returned to other jobs and pursuits in rural districts and the

7. See the SDC Sustainable Artisanal Mining project website: http:// sam.mn. city. Head-counting exercises, then, are likely to capture only a proportion of those involved. Second, the gap reflects the fact that the numbers of people engaging in the practice has dropped markedly since the boom in the early to mid-2000s. The SDC, for example, has revised its estimate of the numbers of artisanal miners in 2015 down to 60,000 . It is interesting to note, however, that the older estimate of 100,000 ninja miners continues to circulate in press reports (e.g., Brook 2015; Laiz and Rengel 2014).

\section{The Sustainable Artisanal Mining Project and the Unsustainable Ninja}

The tenor of development agency treatments was that the Mongolian government should view artisanal mining as a form of poverty alleviation, comparable to similar self-help strategies found in Africa and elsewhere in the developing world. ${ }^{8}$ In 2005 the SDC launched the Sustainable Artisanal

8. This logic led to proposals for partnership schemes in which external agencies would operate with the government to create a legitimate small-scale mining artisanal sector and develop the local economy in rural areas. Following these recommendations, the SDC strongly advocated for legislation to allow the formalization of the sector through the establishment of officially recognized mining organizations. This position reflects international policy debates surrounding small-scale informal mining elsewhere. Siegel and Veiga (2010), for example, identify two broad policy positions on artisanal mining in general, throughout the 
Mining Project (SAM project). The SDC characterized artisanal and small-scale mining as a poverty-driven subsistence activity that engaged over 100,000 people, primarily former herders and laid-off factory workers who extract tiny gold nuggets and, to a lesser extent, coal and fluorspar from unsafe, illegal castings and waste heaps. In the SDC narrative, informal artisanal mining was at risk of becoming a vast, uncontrollable process, resulting in serious social and environmental impacts. If the sector was properly formalized through laws and regulations, the argument went, it represented an enormous potential for local development and rural income enhancement (SDC 2012b:1). The main goals of the project, therefore, were to gain recognition for artisanal mining as a formal subsector contributing to Mongolia's economic development and to provide the training and "capacity building" to develop an "economically sustainable, environmentally responsible and human rights based ASM sector in Mongolia benefiting from, and contributing to, global best practice regarding artisanal and small-scale mining" (SDC 2015:1). ${ }^{9}$ The main vehicle for formalization was to be the nongovernmental organization (NGO; töriin büs baiguullaga) made up of one or more mining teams termed "partnerships" ( nökhörlöl). An NGO could then be legally registered, pay taxes, and enter into a three-way agreement with local government and a mining company to be granted rights to work a plot of land.

Judging by its publicity material, the SAM project appears highly successful (SDC 2015, 2016). By the start of 2013, more than 550 partnerships had been established across the country, with a total membership of about 5,000 artisanal miners. Around 50 plots of mining land had been granted to partnership NGOs, totaling some 740 hectares. ${ }^{10}$ The project also organized training, meetings, forums, and conferences engaging international and national research agencies, government officials, and ninja miners. ASM miners who were members of the project visited Latin American countries such as Bolivia and Peru along with project staff and government officials to learn about partnership formalization and the legal position of artisanal mining there.

Of the 200 or more ninja mining sites that sprung up across Mongolia, the largest was in the district (sum) of Zaamar, located some $190 \mathrm{~km}$ northwest from Ulaanbaatar. Zaamar was one of the principal sites for the SAM project. From 2010 to 2013 it claimed to have established 28 partnerships with a

developing world. The first attempts to form the practice into a sustainable livelihood for local miners, and the second tries to introduce alternative livelihoods so as to displace mining altogether. They argued that since it is frequently unrealistic to try to introduce alternative livelihoods, the first approach is often most sensible.

9. The main objectives of the project are the promotion of "professionalism and accountability to facilitate the shift from poverty to prosperity through responsible artisanal and small-scale mining (ASM) and a transparent formal supply chain" (SDC 2016:1).

10. SDC SAM project website: http://sam.mn/mn/sam-project-news /250-2012-08-14-01-36-42.html. membership of 165 people, registered under an umbrella NGO called Enkhmönkh. ${ }^{11}$

One of the authors of this paper, G. Munkherdene, worked as a seasonal ninja miner in Bayankhongor Province (aimag) from 2002 to 2007 and carried out field research among artisanal miners in a number of provinces and districts, concentrating on Zaamar in 2013 and 2014. He got to know one of the seven founding members of Enkhmönkh well, a highly active woman in her midforties that we shall call Bolormaa, who had moved to Zaamar from a neighboring province in 2006 to establish a mining partnership under the auspices of the SAM project. Bolormaa was a veteran development project worker, having engaged with several other rural livelihood projects since 1992 and earning the nickname Tösöl Bolormaa ("Project Bolormaa") in her native district before moving to Zaamar. Since arriving, she had become well known for participating in every local event and initiative.

On paper Enkhmönkh included 23 partnerships with 128 members supported by the project. The NGO was presented as a model for artisanal mining nationally and attracted some media attention. Nevertheless, the NGO collapsed in early 2013 for a number of reasons. Bolormaa explained the failure as a result of incomprehensible and ultimately useless "support" from the SAM project: "The project spent most of the money on the trainers, translators, foreign experts and administrative expenses, not on us. . . . The project did not solve our problems when it came to using land. They bought no equipment for us. I don't understand what the project aims and obligations were" (interview, Zaamar Sum [district], June 2013).

The miners hoped to acquire equipment, funding, and support in negotiating contracts with the local mining companies to allow them to reexcavate some areas that had already been mined for gold using old and inefficient methods. But the local mining companies have simply not granted enough viable mining sites to the partnerships, and the SAM project seemed unable to persuade them to. The head of another of the partnerships, the woman we shall call Gereltuya, explained:

The project . . . write on their website that 20 partnerships are successfully functioning and each member of the partnership earns 700,000 MNT [Mongolian tugrik; around US\$388] per month; but this is not true. To my knowledge, only two partnerships are working, and they work part time ... we only work 2 to 4 times a month. Each time we work for only 2 to 4 hours. Each of us only gets 100,000-150,000 MNT [US\$5583] per month because we do not have enough land to use. . . . For this reason, the project is useless for us. Gold digging is just

11. The NGO's full name was Enkh Mönkh Ergekh Kholboo but was generally known as Enkhmönkh. See National Network for Information of Small-Scale Miners website: https://bichiluurhai.mn/project-details/\%D1 \%8D\%D0\%BD\%D1\%85-\%D0\%BC\%D3\%A9\%D0\%BD\%D1\%85-\%D1\%8D \%D1\%80\%D0\%B3\%D1\%8D\%D1\%85-\%D1\%85\%D0\%BE\%D0\%BB\%D0\%B1 \%D0\%BE\%D0\%BE-\%D1\%82\%D0\%B1\%D0\%B1/. 
a secondary source of income [for us]. (Interview, Zaamar

Sum [district], June 2013)

Project staff, however, described the situation in terms of success and achievement (see, e.g., SDC 2015:18-20; Singo, n.d.). Indeed, at an international forum in Ulaanbaatar in 2015, project staff described Enkhmönkh as symbolic of the project's achievements and failed to mention that the NGO had dissolved 2 years earlier amid bitter disputes over finances that led to legal proceedings.

In many ways this picture is familiar to students of the anthropology of development. It could be seen as another instance of development as a discursive formation that, following Ferguson (1994) and Escobar (1994), consistently fails to help poor people. The mismatch between the goals of the project staff and those of the recipients, for example, seems to answer well to Mosse's (2005) characterization of development policy. $\mathrm{He}$ notes that whatever its official claims, a policy primarily functions to mobilize and maintain institutional political support; its primary purpose is generally to legitimize itself rather than to orient practice. Furthermore, policy models that work well to legitimize and mobilize political support frequently provide a poor guide to action. ${ }^{12}$

What, then, was the substance of the differences between the development project representation of ninja mining and the understandings of those actually engaged in the practice? One central difference was that while the project was concerned with the formalization of mining as an occupation, those doing mining work were concerned with access to resources - primarily the gold-bearing land needed for excavation and, to a lesser extent, the equipment required to make the work practicable.

The primary aim of the project was occupational - to insert "micro miners" into the formal economy to permit professionalization and regulation. This was an appealing goal, well able to mobilize the necessary political support. A quarter of a century after the collapse of state socialism, the idea of secure salaried employment within a recognized profession remains an overwhelmingly popular aspiration throughout the country. The prospect of transforming precarious self-help gold scavenging into "proper" jobs was highly appealing to many of those involved, as well as policy makers. The environmental and social costs of unrestricted ninja mine workings were causes of public concern throughout the country, fueling calls for regulation. Seen in terms of artisanal mining as an occupation notionally found throughout the world, the project goals seem perfectly well judged.

But if one locates the gold rush in the wider picture of Mongolia's political economy, a different understanding emerges. Throughout the 1990s the bulk of the population had been concerned with the hunt for sources of wealth. Like the derelict

12. Mosse (2005) makes three further points: that development projects work to maintain themselves as coherent policy ideas (as systems of representations) as well as operational systems; that in these systems, projects do not themselves fail-they are failed by wider networks of support and validation; and that success and failure are policy-oriented judgments that tend to obscure project effects. factories and piles of scrap metal, the basis of the gold rush was a transformation of the resources generated by the old Soviet-style economy. In this case, however, it was rooted in a knowledge product.

\section{Production of a De Facto Public Resource}

Extensive Soviet-Mongolian geological survey work carried out in the 1970s and 1980s had discovered vast amounts of mineral resources, including large amounts of ready-to-mine alluvial gold deposits. ${ }^{13}$ In the 1990s, in an attempt to create business opportunities, the Mongolian state made public the previously secret mineral survey materials of the State Geofund. This formed part of the government's Gold Program that granted exploitation licenses and loans to mining businesses and triggered a company-driven gold rush in 1994 (Grayson 2007:3).

Many geologists, mining engineers, and mine workers had been made unemployed by the collapse of state companies. They lacked the wealth needed to buy mining licenses, but they had the skills and simple tools needed to exploit the new public resource that had been inadvertently created - the knowledge of where to find accessible gold deposits. A lack of authorization was not a powerful disincentive. The collapse of state socialism had undermined both the state's moral authority and its ability to enforce laws, and all sorts of illegal activity mushroomed in the 1990s. Mongolians had learned that if something of value was there for the taking, then someone generally took it.

The first wave of unauthorized gold digging emerged in 1995-1996 and was highly skilled, involving relatively small numbers of former miners and their families, probably a few thousand people at most. Zaamar was one of the first sites for this activity. Large numbers of locals joined the backbreaking but profitable early wave of "ninja" mining. The expansion of mining by private companies in 1997-1998 drew many of the skilled miners back into regular employment, but in 1999 economic conditions worsened in Mongolia as a whole, and illicit mining began to attract tens of thousands of people in what Grayson (2007) called "the people's gold-rush" (4).

Far from retaining "rural people" in the countryside, the gold rush produced waves of seasonal movement from all over the country, including large flows from the city of Ulaanbaatar itself. Ger (yurt) settlements of thousands of people, with temporary shops, bars, and service traders, appeared for the thronging summer season and shrank back to a small core over the winter months. The most famous of these sites appeared in 1998 in Zaamar on the banks of the Tuul River, known as Persiin Bulan (Persian Gulf) because the proliferation of mining teams there

13. In the case of Zaamar, joint Russian-Mongolian geological expeditions began searching for mineral resources in the late 1970s. From 1979 onward, a number of survey expeditions were carried out in this area, including the Darkhan Geological Search Expedition and a survey by the Janchivlan Geological Company. In 1984, Russian geologist A. I. Kirsanov estimated the overall size of the alluvial gold deposit of the Tuul River at 74.9 tonnes. From 1984 to 1987, the Darkhan Geological Search Expedition extensively drilled the Tuul Valley (Karpoff and Roscoe 2005:23-24). 
could be ironically compared with the US military buildup in the Gulf War of 1990-1991.

But the bulk of those engaged in such mining were not there to enter a new occupation or to become full-time miners. They were there to access a relatively new form of de facto public resource, the gold that lay in the ground and that at present was relatively free for the taking - albeit at the price of grueling hard labor. Many of those working the goldfields over the summer months were from herding families, many were students, others unemployed workers. They worked for money to realize some other goals they might have, and they would stop when they had earned enough, had to return to their other activities, or could simply bear no more of the grueling work.

\section{Enclosing the Gold-Mining Commons}

The gold rush peaked around 2006-2007, and since about 2009 the numbers of those involved have declined by all accounts. This was not because of an expansion of alternative sources of livelihood or because the demand for additional income has declined. The principal cause is that the mining companies have been increasingly successful at enforcing their legal rights of exclusion. As mining companies have expanded the scope of their operations, the areas left for illicit exploitation have shrunk. Companies have also been more successful at enlisting the state in the defense of their interests. The rule of law has increased since the 1990s, and the police have become more active in preventing and punishing "ninja" activity. Despite SDC lobbying, the Mongolian state has made only the most minor modification to the relevant laws. ${ }^{14}$ Mining companies have made increasing use of private security guards to patrol and enforce exclusion zones. The de facto gold-mining commons have now been largely enclosed by private company owners. ${ }^{15}$

This process is illustrated by the stories of three Zaamar residents, whom we shall call Boldbaatar, Batbayar, and Tuya. Aged 27 at time of writing, Boldbaatar's family had lost all but 150 of their livestock in the harsh winter $(z u d)$ of 2002 and moved to Zaamar from another province. His father found work in a local Mongolian-Russian joint mining company, and the

14. A 2010 amendment to the Law on Minerals (4.1.23) allows local government to grant access to certain categories of land to micro-mining groups made up of district residents within registered partnerships (nökhörlöl) or cooperatives (khorshoo; State Great Khural, Mongolian Law on Minerals, Ulaanbaatar: House of State, 2006:2). In practice, however, access to gold-bearing land must generally be agreed by the relevant mining company as well as local government.

15. It should be noted that although the expansion of company mining has drastically reduced ninja opportunities, it has also entailed some increase in the number of people in formal employment in the sector, an arguable improvement in the prospects of effectively monitoring environmental damage, some increase in tax revenue, and other effects widely seen as positive. A full evaluation of the social, economic, and environmental effects of these changes lies beyond the scope of this paper, however, which is primarily concerned with describing the nature of the historical processes under way. rest of the family herded their livestock; a series of good years allowed them to expand their holding to 800 head. Until 2004, when he finished high school, Boldbaatar and his friends would go ninja mining in the long summer holidays. Boldbaatar's sister went to university while he stayed to work with the livestock and do informal seasonal mining, a common pattern among Mongolian rural families, many of whom keep at least one son at home to herd livestock but are keen to invest in the education of other children, frequently daughters.

After around 2006 it became increasingly difficult for Boldbaatar and his old school friends to get access to the gold sites in the face of expanding company security. Their main tactic became one of effectively stealing soil from sites and bringing it off company land to process it for gold. But they were caught by guards more and more frequently. At first punishment tended to be confiscation of any gold and being forced to do chores for the company such as cutting wood, cleaning buildings and gers, fetching water, and so on. Later, however, the guards would punish them with beatings, secure in the knowledge that the "thieves" would not report them to the local police. In 2009-2010 another harsh winter (zud) killed all but 100 of the family's livestock, and Boldbaatar and his father joined one of the SAM project-sponsored partnerships in the hope of gaining legal rights for small-scale mining (fig. 3). However, although the partnership managed to establish the recommended agreements with local government and a large mining company, the actual allocations of land made by the company to the partnership were very few and far between - too small to allow partnership members to make more than a pittance. As a result, Boldbaatar would work "legally" when the partnership was allocated some land to work, and when this was exhausted, he resorted to the tactic of stealing soil. However, the increasing difficulty of both methods meant diminishing returns from mining, and by 2013 Boldbaatar was looking to pastoralism for his future livelihood. Provided he could expand his herds, he was ready to drop out of mining entirely.

The situation of the couple we shall call Batbayar and Tuya was rather different. In their midforties and both born in Zaamar, Batbayar and Tuya are shop owners and local gold traders who spend the summer months selling goods to ninjas and locals in Zaamar and the winter in the three-room flat they own in the capital city of Ulaanbaatar. Batbayar completed professional training as a tractor driver, but after the collapse of the old system, he, like so many others, lost his job and made a living by herding livestock. When the first private mining companies began to operate in the district around 1993, Batbayar got a job as a driver. Tuya had been training to be teacher in the district school, but job prospects collapsed in the 1990s. They married in 1995 and their daughter was born the following year. The couple planned to go to South Korea as migrant laborers, but only Tuya received the necessary visa, and Batbayar lost his job in the confusion. Batbayar started ninja mining in 1999 to support his mother and daughter. Tuya sent money, and with it the family opened a kiosk shop (tüts) in the subdistrict (bag) 


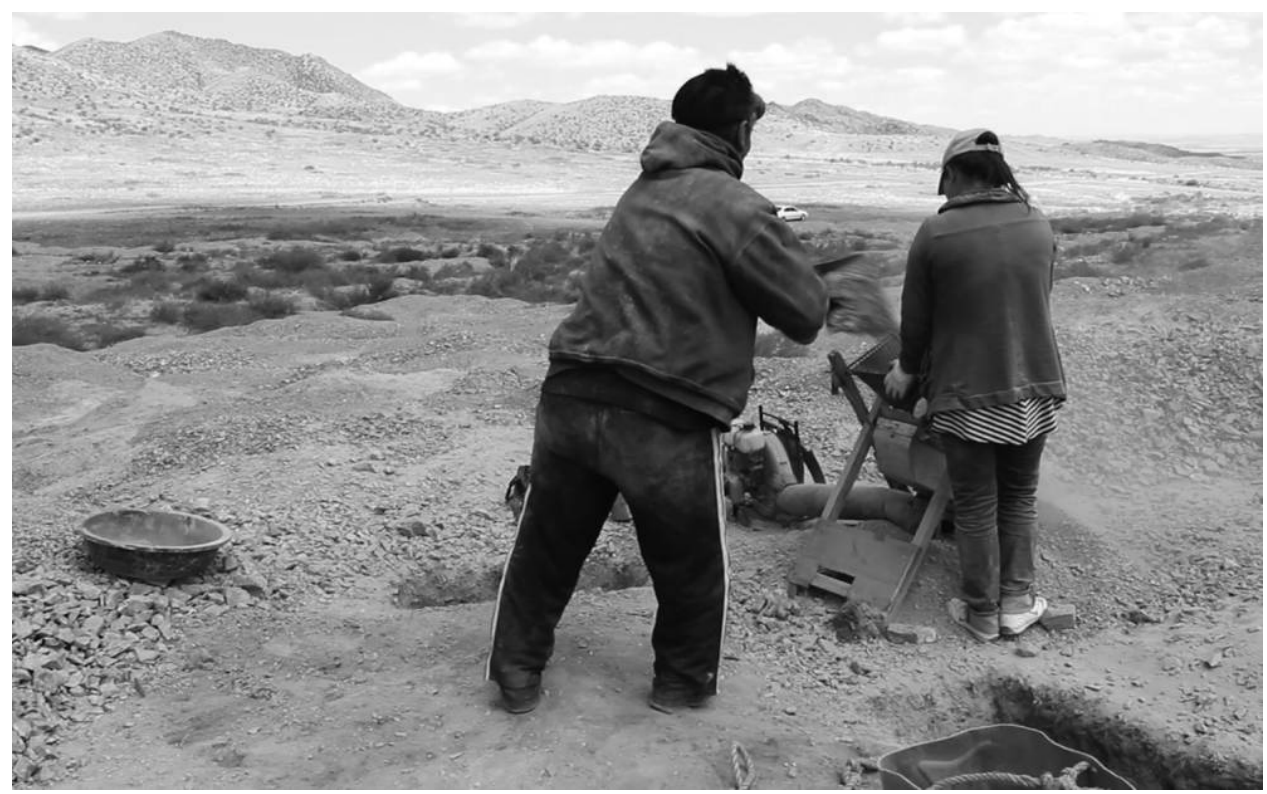

Figure 3. Boldbaatar's father and younger sister sifting alluvial soil using gravitation. Zaamar, June 2013. Photo by G. Munkherdene. A color version of this figure is available online.

center closest to the main goldfields. Batbayar helped run the kiosk and took up mining opportunities whenever they appeared. In 2008, after 6 years in South Korea and 3 years in the United States, Tuya returned. The family now has a large shop, a gold trading business, and three children, the eldest of which they hope to send to the United States to study English at school and business or economics at university.

Batbayar is a member of another of the SAM projectsponsored partnerships, which he joined in 2011. Relatively wealthy and with a successful local business, Batbayar hardly matched the image of a desperate member of the precariat. He explained his reasons for joining in the following way:

There's no one who doesn't like money. [Micro mining] is not my full-time job. . . . My first profession is that of driver. Maybe [you could say] my second is as a ninja. Indeed, I thought that the partnership would give us a new chance to dig for gold and make money. But it hasn't. The project people told us so many good things. But those words were false. My partnership is not permitted any land now. It has not worked successfully since it was established. We are just waiting for news from the boss of the partnership. This year we've been able to go gold mining just six times. It is not a profitable job.... Everybody has their own job or something else to do. Some of them are herders, some of them are workers in companies in Zaamar, and some of them are businesspeople like me. If the company gives us land, then we work on this land. If not, we can only steal soil from company land. But we need to live. Life is tough. (Batbayar, interview, June 2014)

This is a matter of political ecology, as Escobar (2006) applies the term, following Martinez Alier, that is, "conflicts over access to, and control over, natural resources, particularly as a source of livelihoods" (8) ${ }^{16}$ But for anthropologists, "the natural" is a social construct, and conceptualizations of the environment are produced by "ever-changing historical contexts and cultural specificities” (Descola and Pálsson 1996:15). The gold-mining commons existed within the distinctive and intensely historical environment of the Mongolian landscape. To understand it, then, we need to examine its particularities.

Historically, rights to land on the Mongolian steppe have been rather different from those of individual private ownership. Mobile pastoralism, which dominated the economy until the 1960s, and which remains central to most rural livelihoods, involves the combination of exclusive rights to the use of some areas of land with more public access to other seasonal pastures, regulated by local political authorities. This was true of both prerevolutionary and collectivized pastoralism. Although the introduction of the Soviet-inspired negdel collective farms, with their bureaucratic structures and mechanized support facilities, represented a radical break with the past in many ways, in some respects the new institutions resembled the older monastic and aristocratic estates that they had replaced. Individual private ownership of land in the current commercial sense was not a possibility in either of these political economies. In the prerevolutionary era, land "belonged" to the emperor, to the prince of

16. "Joan Martinez Alier (2002) defines political ecology as the study of ecological distribution conflicts. By this he means conflicts over access to, and control over, natural resources, particularly as a source of livelihoods, including the costs of environmental destruction. 'Ecological distribution conflicts,' however, exist in the context of economies, cultures, and forms of knowledge." 
the district, and to the spiritual "masters of the land" (gazaryn ezed, sabdug, and lus) of Buddhist cosmology (Sneath 2014:461). In the state socialist period, land ownership was assigned to the sacralized nation-state and its people, with access to pasture administered by the officials of the collective and state farms. In neither period was access to grazing land a free-for-all; local authorities always regulated land use among those entitled to use it, and excluded others. But the landscape remained, in some senses, public; it could not be held by individuals in the same way as mundane possessions could.

Much of late nineteenth- and early twentieth-century history of the region can be seen in terms of competing property regimes for land; the confrontation between "custodial" mobile pastoral Mongolian rights to territory on the one hand, and the more individual and commercial ownership forms of Chinese agriculture on the other (Sneath 2004:166-170). The advance of Chinese settlement in Inner Mongolia created widespread unrest and helped fuel the independence movement that led to the establishment of an autonomous Mongolian state in 1911 (Lattimore 1934:114). By the end of the twentieth century, land ownership had become the subject of dispute once more. In the 1990s the ADB and other international development agencies strongly recommended the introduction of legislation allowing the private ownership of land. But the Mongolian parliament consistently refused to allow pastureland - the vast majority of the Mongolian landscape - to be privatized, although it did introduce a private property regime for urban land and a system of certification that gave rights of "possession" (ezemshikh) for certain pastoral sites. This reflected a widespread public feeling that land should remain, in some senses, public. This is not just a pastoral sensibility; throughout the state socialist period, and still to some extent today, families would leave the urban centers and spend the summer months with relatives and friends in the zuslan - summer pastures and camps. Those with motor vehicles expect to be able to drive them pretty much anywhere they can physically go. Mongolians feel entitled to their national landscape.

It was in this historical and sociocultural context, then, that unauthorized micro mining boomed. Most of the companies that had hastily bought mining licenses in the 1990s could not enforce their exclusive rights to the land concerned. Neither could the tiny underresourced police forces in the localities concerned, particularly because at first the activity seemed to occupy a moral and perhaps legal gray area.

The extension of de jure and later de facto corporate ownership to the mineral resources of Mongolia resembles Marxist concepts of primitive accumulation or what Harvey (2005) describes as neoliberal "accumulation by dispossession"- the "corporatization, commodification, and privatization of hitherto public assets" (160). ${ }^{17}$ However, in the longer term we ob-

17. Similarly, the historical process would match Tsing's (2015) notion of "salvage accumulation"- the amassment of capitalist wealth through the conversion of material with other histories of social relations. serve a process that, following High (2010:153), can be termed resourcification: the introduction of discursive formations in which items appear as resources - that is, sources of potential wealth. The practices and discourses of state socialist geology transformed the mineral content of land into a potential resource. These originally state resources were transformed again into commercial and, inadvertently, into de facto public resources by the state's release of Geofund materials. The new discursive regime was not undisputed, however. Some narratives within public culture rejected, or at least qualified, the notion of land as a resource for mineral extraction. Buddhist and shamanic narratives commonly stressed the dangers of ignoring the spiritual owners or masters of the land used for mining (High 2017; Sneath 2014:467), and some lamas are now regularly engaged by companies to perform appeasement ceremonies for local spirit masters before starting new mines (High 2013:761, 2016:80). The diverse discourses surrounding land, landscape, and property often include cosmological references, and links are often made among environmentalist, Buddhist, shamanist, and nationalist positions in protests and political movements. ${ }^{18}$ But such narratives feature relatively rarely in the everyday discourses of unauthorized miners, many of whom are privately agnostic as to the existence of local spirits. Almost as soon as it became a recognized source of wealth, gold-bearing land became subject to the discourse of resources (nöots).

\section{Rights of Access and the Notion of the Nutag (Homeland)}

The concept of nutag, meaning homeland or territory, has become a central value in private and public discourse. Used to evoke emotive attachment to the "home," it can operate at different scales so as to apply to a locality, district, province, or the entire nation (Mongol nutag). It has become a central term in all sorts of political and cultural projects (Sneath 2010:258). The 1990s saw a proliferation of organizations called "homeland councils" (nutgiin zövlöl), for example. These recruited members of the business, political, and cultural elites to represent the interests of localities and provinces through fund-raising, lobbying, and preferential treatment (Sneath 2010). This reflects a powerful sense of localism that we term "nutagism": a transposable nationalist-style logic of attachment that can be used discursively to root persons in places and to make claims as to who is entitled to what.

Entitlement to resources has become a central value in personal and political sensibilities. This concern with rights of access surfaces continually in people's narratives and descriptions of the situation. Zaamar residents, almost all of whom have been involved in unauthorized mining networks, generally resent the "outsider" ( gadny) ninjas who flooded in and out of the district. A popular view among district (sum) residents is that only locals

18. For shamanic narratives on mining, environmentalism, and resource nationalism, see Shimamura (2014:404-406). 
should be allowed access to the district's goldfields, because they are in their "homeland" (nutag). Residents of the subdistrict (bag) tend to the view that only subdistrict residents should have such rights, for the same reason, because the gold is in their nutag. Miners from outside the district point to Article 6.1 of the Constitution, which states that the land and natural resources of Mongolia shall be subject to the "people's power" (ard tümnii medeld) under "state protection" (töriin khamgaalaltad). ${ }^{19}$ The land belongs to all citizens of the Mongolian homeland, they argue, and they have a moral right to use it. Wherever they were from, members of a micro-mining team frequently resent others who might compete with them.

In the goldfields themselves, miners tried to continually monitor the productivity of the other plots, watching how much gold the team seemed to be finding and occasionally inspecting the workings by stealth if opportunity arose. Areas thought to be markedly richer than the others were liable to have soil "stolen" from them if unattended or to be taken over entirely by one of the larger and more intimidating teams. News of people being pushed off their plots circulated continuously, and the usual reaction was to assume the soil there must be particularly rich in gold. In some cases, one team would mobilize several others to mount a joint "attack" (dairakh) or "robbery" (bulaakh) on a working thought to be particularly valuable. In these disputes the larger teams with better local networks generally had the advantage because they could mobilize larger numbers and the only real arbiter of competing claims was physical force. ${ }^{20}$ Fights were common, particularly in the evenings when many people drank vodka, and one of the most important root causes was competition between teams. As a result, team members were cagey about how much gold they were finding. Much effort went into maintaining de facto rights over good plots, and this could only really be achieved by the threat of physical force. Teams frequently posted members at their workings overnight in the summer months to try to prevent other teams occupying or stealing soil from them. ${ }^{21}$

This need to defend access to resources mirrors rural experiences of disputes over grazing land. The economic collapse of

19. The next article of the constitution, Article 6.2, however, states: "The land, except that given to the citizens of Mongolia for private ownership, as well as the subsoil with its mineral resources, forests, water resources, and wildfowl, shall be the property of the State." This article is hardly ever mentioned in this context.

20. One such takeover, witnessed by one of the authors in April 2010, took place in a goldfield called "Altan-Uul" in Biger Sum, Gobi-Altai Province. Most of the teams were facing disappointing yields at the time, and a rumor circulated that the plot of a team from a more distant sum (district) contained rich deposits. After some mutual encouragement, several other teams mounted a joint invasion of the site. Outnumbered by locals, the original plot occupants could only watch as "their" site was taken over and mined by others.

21. Some teams monitored prime gold-digging plots in the winter and early spring to try to keep others off "their" spots until the team could start work again when the weather improved. the 1990s drove tens of thousands of families to start herding for the first time. As they lost their jobs, large numbers of Mongolians tried to make a living raising livestock. This trebled the number of workers directly reliant on pastoralism for their livelihood from less than $18 \%$ of the national workforce in 1989 to $50 \%$ of the working population in 1998 (National Statistical Office of Mongolia 1999:45, 95; Statistical Office of Mongolia 1993:6). These "new herders" (shine malchid) attracted much criticism, not only for their poor pastoral judgment and lack of skill but for their tendency to move with their livestock onto the seasonal pastures of other districts and households and graze off the vegetation used by locals. In this case, however, local district authorities could be invoked to settle disputes and exclude those without rights to land, and they became increasingly effective at doing so. But the anxieties and conflicts surrounding access to pastureland helped fuel defensive nutagism, and a powerful response to the hardship of the 1990s was the impulse to protect access to local resources, be they pastoral, political, or mineral.

\section{Conclusion}

In retrospect, the story of ninja mining reflects three intertwined processes that have shaped contemporary Mongolia. Over the long term we see processes of resourcification whereby the different regimes of value for land in prerevolutionary, state socialist, and neoliberal Mongolia created new resources and attendant property regimes. The latest of these regimes was, at first, simply unenforceable in the face of the popular reaction to the appearance of accessible gold as a resource. Interestingly, given the history of Mongolian attitudes toward land, the default property regime for the gold-bearing areas was a de facto commons, whatever its legal status. Far from being rapidly naturalized under market conditions, the new private property regime had to be imposed and maintained by force, using company guards and police. Placed as it was outside political authority, however, the new commons was far from harmonious. Contra Lockean notions of property, in which the application of labor to matter creates natural rights of ownership over it (Locke 2007 [1689]:42), working on a specific plot gave no recognized rights, and powerful mining teams evicted weaker groups if they felt like it. Partly, of course, this reflected the illegal status of the activity. But it also reflected the method by which land could be made to realize value. The goal was to extract the gold and move on, and ninjas have no interest in retaining property relations to land after working it out. Unsurprisingly, then, the disputes over land for mining did not display the sort of agricultural logics of the Paraguayan peasants studied by Hetherington (2009) for whom long-term cultivation of land gave moral rights of ownership over it. The critical factor for ninja miners was the ability to gain access to land and use it, not to own it; and in this respect, it resembled mobile pastoralism, in which the land ultimately belonged to higher authorities and rights to use it were a matter of political entitlement. Conflicting notions as to who should have access to gold-bearing land followed a similar logic, reflecting the central importance of the 
concept of the nutag in which entitlement to resources follows from attachment to the homeland.

In addition, we see that the reaction of the development sector to the people's gold rush was to approach micro miners in occupational terms, as a workforce lacking certain forms of knowledge and organization, and therefore in need of expert advice and training. Instead of the cash and equipment they hoped for, the miners were given "knowledge exports" from the developed world: lectures, workshops, and seminars. ${ }^{22}$ These were results that the project could deliver, whereas the fundamental issue of legal rights to gold-bearing land could simply not be addressed within the private property regime without incurring enormous financial costs. Unless the project could afford to buy mining licenses, the best it could hope for was to beg companies for access to workings thought too poor to be economically viable. This was, to be sure, better than nothing. But because micro mining had been presented as a potential full-time occupation, rather than as a supplementary source of income, the small plots of mining company leavings were simply not enough to satisfy expectations. In retrospect, the vision of a professionalized, regulated artisanal mining sector seems unrealistic without legal rights to substantial deposits, something made prohibitively expensive by the private property regime for land and beyond the means of development projects committed to working within it.

Last, we see how divisive the production of new resources can be, how generative of conflict and competition. The companyled and subsequent people's gold rush led to countless conflicts of access, a competition that the companies are definitively winning. Although development goals include the promotion of "community" (Asia Foundation 2006:1; SDC 2015:15), ${ }^{23}$ the small niche created for legal micro mining has produced new sites for local competition and conflict over resources - the few allocations of gold-bearing land that the mining companies do make. The governor of the subdistrict (bag) containing the Zaamar goldfields complained, for example, that the district (sum) governor routinely blocked requests for grants from the subdistrict so that he could award any that were available to his family and friends (Bayarmaa Altangerel, interview, June 2013). ${ }^{24}$ Indeed, the project itself represented a resource to be exploited by formal or informal means. As the viability of

22. See Sneath (2003:454) for discussion of other such knowledge products.

23. See SAM project website: http://www.sam.mn. See also Creed (2006) on "community."

24. Bayarmaa Altangerel is a governor of the Khailaast Bag of the Zaamar Sum. On paper there are 20 registered partnerships in the subdistrict as part of the project. However, in 2013 only two of these were actually operating, and even these were only working intermittently, usually for only a few days a month. These two partnerships are supposed to work within the authorized site, in line with the contract established with the company that owns it. In reality, however, the mining teams constantly encroached illegally on other unauthorized sites they felt had richer deposits. Although these two partnerships work within the same project, they mining declined, a number of people involved in the project began to divert the small amounts of investment funding available to other projects such as vegetable growing instead of forming mining partnerships. This is characteristic of the wider development sector in Mongolia, in which results can be created on paper if not in fact so as to make the most of available opportunities. Having "mined out" the SAM project, key members of the Enkhmönkh are now looking for other development projects to engage with. And yet the prospect of transforming opportunistic resource exploitation into sustainable livelihoods remains as elusive as ever.

\section{Comments}

\section{Naran Bilik}

Institute of Anthropological and Ethnological Studies and Center for National Minorities Studies, School of Social Development and Public Policy, Fudan University, 1010, Wenke Dalou, Guonian Lu, Yangpu Qu, Shanghai 200433, China (naranbilik@163.com). 23 I 18

As Polanyi pointed out, "market forces taken to an extreme would destroy democracy and a functioning economy" (Kuttner 2017). This prophecy can serve as a tracer to follow the trajectory of social development after the state social economy collapsed in Mongolia; it can also serve as a canary in a coal mine for other postsocialist countries or reforming socialist countries with "local characteristics" such as China. With the wider transformation of political economy and globally expanding conditions of precarity in mind, G. Munkherdene, a Mongol native and a former "ninja" miner, and David Sneath, an anthropologist specializing in Mongolia and Inner Mongolia, have made an in-depth analysis of the disheartening conditions and the deplorable dilemma that many Mongolian artisanal miners found themselves trapped in. Several points raised by the article merit our attention.

First, international agencies such as the Swiss Agency for Development and Cooperation (SDC), aiming at properly formalizing informal artisanal mining through laws and regulations and promoting local development and rural income enhancement, failed to meet the immediate needs of the local miners, who would rather have the gold-bearing land for excavation and the equipment required to make the work practicable than the training and "capacity building" provided by the agency. The agency failed to contextualize anthropologically the particularities of local conditions, and they did not take into account those dimensions that no internal agencies can afford to ignore: history, culture, and power. Especially in terms of power, the primary purpose of the government is to legitimize itself and to mobilize political support rather than to guide action. In the

have a very uneasy relationship and frequently complain about each other to the project leaders. 
same way, the nation-state makes use of UNESCO's Intangible Cultural Heritage to solidify its national boundaries and make them more "tangible" (Herzfeld 2014).

Second, prerevolutionary, state socialist, and neoliberal Mongolia created different regimes of value for land. Each resultant resourcification, again, led to changes in human relationship and the relationship between humans and the land. The story of "ninja" mining testifies the desperate, seemingly hopeless, efforts with which those late-development countries such as Mongolia try to catch up with developed countries in terms of economy if not completely politics. According to anthropological wisdom, the boundaries of culture, history, economy, and politics usually do not coincide. Any reform including poverty-alleviation programming has to take into account the culture and history of targeted regions. The present situation of Mongolia is a result of processual negotiations that involve a plethora of human and nonhuman dimensions. Clifford Geertz (2000) has quite relevantly said that any politics "have to be targeted, tailored to circumstances, to times, and places, and personalities."

Third, the authors captured dynamic, local performative understanding of nutag, meaning "homeland." By evoking its indexical connection to the "home," what is signified by the word can be expanded to include the entire nation in addition to a locality. Therefore, it helps the locals to claim exclusive rights over the land according to their in situ definition of nutag. Despite the fact that the Mongolian way of life is not necessarily all based on nomadism, their "nomadic ideology" is not pure imagination. Owen Lattimore accurately pointed out the divide between "the right to move" and "the right to camp" when depicting the confrontational mutuality that existed between pastoralists and agriculturalists in Inner Asia (Lattimore 1951: 66). Mobile pastoralism, supported by "nomadic ideology," "involves the combination of exclusive rights to the use of some areas of land with more public access to other seasonal pastures, regulated by local political authorities." In both the presocialist and the state socialist periods, such public access to land, though not without regulation by local authorities, had been maintained. It is interesting to compare the notion of "state" or "nation" in Mongolian and in Chinese. While the Chinese word guo graphically depicts a population with weaponry standing on a piece of land, protected on four sides by walls, the Mongolian equivalents, ulus and oron, mean "people" and "position," respectively, and do not involve land or walls. In connection to such conceptualization of and their traditional attitudes to land, "the default property regime for the gold-bearing areas was a de facto commons." However, with an increasing pace of resourcification, as mentioned in the article, "a de facto public resource was created . . . only to be progressively privatized and enclosed by increasingly powerful mining company interests." Whereas ninja miners try to gain access to land use, not its ownership, mining companies aim to enclose the land by acquiring licenses and expel those ninja miners step-by-step. Meanwhile, among ninja miners themselves, powerful mining teams could evict less powerful teams when necessary.
Fourth, the authors provided a persuasive critique of the Lockean notions of property, which claims that "the application of labor to matter creates natural rights of ownership over it." The fact in Mongolia is that working on a piece of land does not lead to recognized rights over it. We are now back to Polanyi, who said that extreme marketization would destroy democracy and a functioning economy. He is right.

Fifth, the authors have pinpointed the problem of lacking legal rights to substantial deposits, which rendered unrealistic the efforts of professionalizing and regulating mining sectors. In relation to this problem, officials at higher levels often blocked requests for grants from the subdistrict so that they "could award any that were available" to their family and friends. It is a common problem for postsocialist and reforming socialist countries: the merger of power with the pecuniary creates horrible corruption and extreme social and economic discrepancy between the rich and the poor. Between neoliberalism and state socialism, is there a third way?

\section{Gregory Delaplace}

LESC, Maison de l'archéologie et de l'ethnologie, 21 allée de l'université, 92023 Nanterre Cedex, France (g.delaplace@yahoo.fr). 5 III 18

A traveler stepping into a ger - the Mongolian collapsible felt tent - can expect to be presented with a series of goods: tea, a platter of cheese products and fritters, perhaps cigarettes, snuff tobacco, and possibly alcohol. It is important according to the hospitality etiquette that all these things should be offered in an open manner to a guest - the tea and alcohol served, the platter displayed, the pack of cigarettes gaping, and the snuff bottle's lid slightly ajar. By extension, all supplies surrounding the guest that are "in the open," "available" (il zadgai), such as books stacked away between the roof and the roof-poles, newspapers, food, or else, are generally up for grabs. Conditions apply, of course: anything that has been put on the household's altar is off-limits; more generally, one cannot appropriate all of one thing, but only a part and indeed a part that does not compromise the whole (a few cheese crumbs on top of the platter, one cigarette out of the pack, one sniff of tobacco, or half a page from a book as rolling paper). On the other hand, the goods in a ger that are hidden or locked away, even if their location is known to the traveler, are not for the taking - thus the content of the house's trunks and baskets, or of any closed bag for that matter (see Empson 2011:116 et seq.). Therefore, displaying goods is usually a sign they are potentially exploitable (unless they are for sale, of course), whereas conversely leaving out in the open stocks that are not supposed to circulate-like the content of the "fortunecalling bag" (dallagiin uut), for example - is a sure way to jeopardize a household's "fortune" (khishig; see Chabros 1992).

This fundamental contrast between supplies that are exploitable and supplies that are not relates to one of the central questions addressed by G. Munkherdene and D. Sneath in their 
paper: What counts as a resource in Mongolia? In this respect, the opposition between things hidden and things openly available seems indeed pivotal. What lies or grows aboveground tends to be considered free for use and is generally treated as commons. The conditions mentioned earlier would apply as well: one is only entitled to a part of any openly available resource so long as it does not compromise the whole. Thus, a few dead branches out of a tree or a few dead trees out of a wood, but never the last few branches or a single standing tree; the basic trope of resource exploitation in Mongolia is indeed grazing: this is what herders let their livestock do before they (ideally) move to another pasture, but this is also how anyone is basically expected to act toward available resources.

Therefore, I do not think that, as one often hears, it is for fear of digging the ground per se that Mongolian people tend to regard mining as a morally ambiguous activity (digging is not seen as inherently problematic when growing crops, building houses, or burying corpses) but rather because of a general and much deeper unease with the appropriation of things that are not for the taking. Not to mention the fact that the environmental pollution incurred in the process of gold mining cannot but give the impression of compromising Mongolian "homeland" (nutag) as a whole - an idea that has been given a vivid illustration by hip-hop singer Gee in one of his songs (Minii nutgiig üldee — "Leave Me My Homeland"; see Irvine 2018).

And yet, as Munkherdene and Sneath's paper shows, everybody does it. What herder does not go "gold-washing" (alt ugaakh) at some point during the summer, before or after having been marmot hunting with his friends and relatives? So, the question really is: Under what conditions can an unavailable resource be nonetheless exploited? In the condition it is so profitable, of course, but not only. The ambiguity inherent to profit made from mining activities has been well stressed by Mette High (2017), and indeed, buried treasures are not always good news in Mongolia. In the course of my own research (Delaplace 2012), I came across stories of families learning they were probably sitting on a stock of gold or silk supposedly buried there by a Chinese merchant before the independence. Upon discovering this, their first move rarely was to grab a shovel and start digging, like a French family would have, were they to suspect some "louis d'or" had been hidden somewhere in their garden. Mongolian families would rather move out, suspecting the gold would prove deadly if dug out and used. Paradoxically indeed, treasures in Mongolia are generally to be found aboveground: they are the infrastructure left behind by socialist institutions, which can be mined at will by the population and sold for parts, or "meteorites" (buumal) found in the open and charged with an energy available to be harnessed by whomever knows how (Pedersen 2014).

So again, under what conditions might a hidden treasure become exploitable in Mongolia? The interesting thing, which makes this paper all the more valuable, is that there is no definite answer yet to this question; it is still a debated one in Mongolia. Some (mainly activists, often backed by shamans claiming to represent the interests of the ancestral homeland) assert that mining resources should not be exploited under any circumstance, whereas others affect not to care, or resort to ritual fixes to make it acceptable and actually profitable in terms of Mongolian concepts of "fortune." Now G. Munkherdene and David Sneath's paper could be seen to point to another way of understanding Mongolian ambivalent response to these qualms. They stress that the resource in this case is not so much gold itself as the "knowledge product" of its localization: geological surveys would have made gold almost as "openly available" as any other resource left there by the previous generation for the next to exploit. Still, not everyone agrees, and the Mongolian gold rush might well be the "test" (sensu; Boltanski and Thévenot 2006 [1991]) after which what counts as a treasureand as resource, fortune, or moral behavior - will need to shift and be granted a new consensual qualification.

\section{Bumochir Dulam}

Department of Anthropology, University College London, 14 Taviton Street, London WC1H 0BW, United Kingdom (b.dulam@ ucl.ac.uk), and Department of Anthropology and Archaeology, National University of Mongolia, University Bldg. No 2, Baga Toiruu 47, Ulaanbaatar, Mongolia (bumochird@gmail.com). 21 II 18

G. Munkherdene and David Sneath argue that the unauthorized small-scale mining known as "ninja mining" or "micro mining" in Mongolia is not simply the result of precarity, poverty, and underemployment, but a response to the appearance of Mongolian natural resources as a new de facto public resource that was created in the wake of the collapsed state socialist economy. Most importantly, they argue that at the heart of small-scale mining are fundamental issues regarding property relations and access to resources. As the authors accurately point out, contesting entitlements to land and access to natural resources enables artisanal miners access to gold resources. In the following, I will expand Munkherdene and Sneath's discussion with three points that may help to clarify why and how the Mongolian response to these "new de facto" resources took the shape that it did.

First, in Mongolia mining sites always become a site for conflict (cf. Bebbington 2012:225; Watts 2004:71-72) between various stakeholders and agencies that claim entitlement. All of them employ different reasoning to justify their entitlement to the land and access to resources. For example, the state and the people (ard tümen) of Mongolia are officially declared as the owners and protectors of the land and natural resources in the constitution of Mongolia. Mining companies have licenses issued by the government. According to the Minerals Law, local district governments have the authority to issue permits to use the land for mining purposes (Ulziibayar and Tsetsenbileg 2010:104). As the authors of this article argue, local people, in turn, justify their rights using the concept of nutag, which is a locality and homeland. And "ninja miners" from other parts of 
Mongolia justify their rights to access to resources using the article in the constitution that declares that the natural resources of Mongolia are subject to the "people's power" (ard tümnii medeld). Both shamanism and Buddhism, on the other hand, hold that human beings are not the masters (ezen) of land and natural resources, but the true masters and owners are the spirits of the locality (High 2017). In Mongolia, all these claims to legitimacy are persuasive, rightful and legitimate in their own terms, and they can have significant power in entitlement conflicts. These contesting entitlements are always intertwined and interpreted differently, which makes the issue of ownership of land and access to natural resources ambiguous and fluid. According to Rebekah Plueckhahn (forthcoming), the division between public and private ownership of land in Mongolia is completely blurred. Ambiguity and blurriness therefore put public resources, in the words of the authors of this article, into a "de facto" or "commons" status.

Second, not only has the appearance of the new de facto public resource resulted in "ninja" or "micro" mining. In fact, all of these resources were always available for Mongolians. Local people used to know which places held what kinds of mineral resources (Murray 2003:118), but extracting mineral resources was taboo (High 2017). Historical documentation — about "gold patrols" (altny haruul), established from the mid-eighteenth century (Banzragch 2004; Nasanbaljir 1964; Tuya and Battomor 2012) to fight against Russian and Chinese illegal gold miners, and local resistance movements against foreign gold-mining companies and Qing policies, to promote mining in Mongolia in the end of the nineteenth and early twentieth century- demonstrates that most of the local aristocratic lords and their subjects seriously considered exploitation of mineral natural resources as something incompatible (harshtai) with the pastoral way of life and beliefs of Mongolians (Sodbaatar 2013:31$33,48,53,54,55)$. For this reason, although mining was present, it was alien to many Mongolians (cf. Murray 2003:115). Here, we can see a strong contrast between the attitudes of Mongolians over 100 years ago and contemporary Mongolians who work as "ninja" or "micro" miners. People's beliefs and perceptions regarding the land and natural resources radically changed over the past 100 years, starting when the theocratic government of Bogd Khan decided to seriously commodify natural resources to fund the emerging nation-state (Batsaikhan 2009:72; Bonilla 2016; Sodbaatar 2013:92; Tuya and Battomor 2012:75-78); continuing with the development of the mining sector in Soviet socialist times; and finally culminating in the latest expansion of the mining sector in the market era. $\mathrm{Al}$ though many Mongolians still consider mining to be inappropriate (Murray 2003; High 2017), these changes have made it acceptable for many Mongolians to work in mining. Even some contemporary shamans I interviewed justified local people's engagement in small-scale gold mining by saying, for example, that if local people do not exploit the gold then nonlocal Mongolians or foreigners will take it anyway: a radical transformation of perspective. In other words, the discussion about small-scale mining is not only a matter of the de facto public resources but also about changes in the beliefs and perceptions of individual agents in terms of the moral possibilities of participating in mining in the first place.

Third, the collapse of state socialism and the neoliberal turn issued in an era understood in Mongolia to be one in which anyone is free to engage in any form of moneymaking (chölööt ediin zasag). The overarching legacy of this tendency has fueled all sorts of economic practices, including what the authors describe as the "scavenger economy." In other words, the regime of the liberal economy created the freedom and liberty for people to engage flexibly in different profit-making practices. The legacy of the regime of economy has inspired people to try different businesses, including those that can be harmful to the environment or that contradict traditional cultural knowledge and teachings.

\section{Lars Højer}

Center for Comparative Culture Studies, Department of CrossCultural and Regional Studies, University of Copenhagen, Karen Blixens Plads 8, bygning 10, 2300 Copenhagen S, Denmark (lhoejer@hum.ku.dk).20 II 18

In this important contribution to the burgeoning anthropological literature on mining in Mongolia and property relations and resource extraction more generally, Munkherdene and Sneath explore the transformations that have taken place in the Mongolian political economy over the past decades through a study of informal small-scale mining. They show how a de facto public resource, emerging in the wake of the collapse of the socialist state in the 1990 s, first gave rise to so-called ninja mining but was then increasingly appropriated by powerful mining companies to the detriment of small-scale miners. Apart from concentrating on the ramifications and implications of this process of privatization and monopolization, they also attend to the role played by development projects in the Mongolian age of the market. I will address each of these contributions in turn.

At the most general level, the article sketches the transformation of property regimes, moving from prerevolutionary and socialist Mongolia to ninja mining and the new neoliberal order in which private property is increasingly "enclosed" and guarded (see also Højer and Pedersen, forthcoming). Ninja mining, the prime concern of the article, appeared in the interstice between socialism and the private property regime of the market, when mineral survey materials from the State Geofund were made public and gave miners access to a de facto public resource, gold deposits, that was "relatively free for the taking." The authors observe that this ninja mining was mainly about extracting gold and moving on. Much in line with mobile pastoralism, they argue, it was as such more concerned with getting access to the use of land than with gaining actual ownership. Although this comparison is appealing and thoughtprovoking, it also gives rise to some questions on my part. To begin with, it would be useful to know how far Munkherdene 
and Sneath would take this analogy. How should we, for example, relate this process of movement (extraction and "moving on") to the stability of "higher authorities," political entitlements to use resources, and the lasting attachment to a homeland, features that they also associate with mobile pastoralism? The ninja economy appears to be based on emerging groups and physical force rather than on established authorities, stable entitlements, and "homelands" only. Could one not also-or rather - see the workings of ninja mining less as a continuation of Mongolian traditions of mobile pastoralism and more as a small-scale illustration of the workings of multinational extractive industries that also aim to "extract and move on"? Would the notion of a "de facto commons" not risk hiding a reality of a not-so-de facto commons where strong ninja mining teams monopolized (privatized?) land much in the same way as mining companies would do nowadays by using guards and so forth? In other words, although I believe that the authors offer a sound description of this process, their ethnography may prompt further reflection on their conclusion regarding a progressive privatization of the Mongolian economy in the postsocialist period. Is the dichotomy between commons and privatization really an adequate one for capturing the specificities of these property regimes? Or should we rather see the process as the progression of more stable and large-scale capital-driven "enclosures" and less as the invention of enclosure/private property as such? So, are we simply witnessing an increasing "privatization," or could we discern different kinds of enclosures? Munkherdene and Sneath's fine, accurate, and revealing description of processes that have taken place in postsocialist Mongolia may thus prompt further reflection on the vocabulary used for describing processes of "enclosure" and, in the end, it may also lead us to challenge more explicitly baseline assumptions about "commons," "privatization," "market," and "neoliberal regimes."

A second contribution concerns the role played by development projects in relation to ninja mining and the new property relations. Munkherdene and Sneath show how a development project was concerned less with orienting practice than with legitimizing itself by creating "an appealing goal, well able to mobilize the necessary political support." This goal was to formalize informal mining through recognition, training, and capacity building. As such, the project never managed to attend to the key problem for ninja miners. This problem was access to resources in the form of gold deposits and not formalization as such. Providing access to resources, however, was beyond the project's financial means, and one may well argue that the project simply did its best with the financial means available. The authors' main critiques of the development project, then, is not that it did not try to achieve its goals but that the project, on the one hand, worked within a vision that was unrealistic, because the project could not afford "legal rights to substantial deposits," and, on the other, that it mainly worked with goals that could legitimize the project itself to maintain political, institutional, and economic support. Yet, they also hint at a more substantial critique when writing that development projects are "committed to working within" a private property regime. This raises a more fundamental (and, in critiques of development, classical) question about the implicit ideological work carried out by development projects. The project worked to help, educate, and gain official recognition of ninja miners, yet did so by accepting the assumptions inherent in the new (private) property regime that also served to undermine the ninja economy in the first place. Working within a discourse of "help" and "recognition," the project thus not only failed to address the fundamental power structures that initially gave rise to the problem but - maybe as an unintentional side effect (cf. Ferguson 1990) — also served to reproduce such property relations in the disguise of "doing good." This critique, I believe, could have been made slightly more explicit, as it may also have alluded to larger questions concerning (side) effects of development projects and the relation between "the formal" and "the informal" as a distinction with strong political implications that may sustain already established property regimes. In this way, the article does not only open new discussions of resource extraction in relation to emerging property regimes in Mongolia, it also contains potentials for critically exploring wider processes, also beyond the Mongolian context.

\section{Byambabaatar Ichinkhorloo}

Department of Anthropology and Archaeology, National University of Mongolia, Ulaanbaatar 14200, Mongolia (bimbamn@gmail.com). 27 II 18

"Enclosing the Gold-Mining Commons" examines the interrelationship of property regime change and mining in contemporary Mongolia and provides detailed analysis of how development organizations justify their intervention. This article also contributes new insights about explaining the root cause of conflicts over "natural" resources between mining companies and local people, including those artisanal or micro miners. The authors argued that the new private property regime in Mongolia made mining companies seek to enclose the "de facto commons" through obtaining licenses, whereas local micro miners still prefer to share de facto commons only with the people who belong to the same locality using the concept of nutag (homeland) and "expanding their social networks to have access to resources” (Ichinkhorloo 2017a:64). Artisanal and small-scale mining (ASM) was translated as bichil uurkhai (micro mining) by Mongolian government and development organizations. This term, "micro miner," is widely used for those formalized "ninja" miners in Sustainable Artisanal Mining Project (SAM project) target sites since 2010. Most official people avoid using the term "ninja," which carries many negative connotations such as selfish, poor, lawless, greedy, and criminal. But micro miners call other nonorganized micro miners XAMO (khamo) or ninja miners. My comments focus on three issues: (1) clarification of de facto commons in mining sites in Mongolia and how these commons persist through cor- 
porate enclosures, (2) development organizations' frequent policy shifts, and (3) types of ninja mining and property relationships.

My first comment concerns the authors' argument about enclosing de facto commons. I am curious to know if these enclosed resources are still defined as de facto commons or private property. If so, for whom? Whose perspective is legitimate in defining the resources as common or private property? Is it state or company or local people or ninja miners or public or others? In other words, are ninja miners "commoning the enclosed resources" again (Gibson-Graham, Cameron, and Healy, 2016:196)? It is not secret that many ninja miners now practice micro mining in places like mining licensed areas or strictly protected areas. For example, many micro miners work in Centerra Gold company's mining licensed area near Noyon Uul, archaeological sites of ancient Hunnu Empire (first century BCE to third century CE), and Khövsgöl Lake National Conservation Park or Great Gobi Strictly Protected Area behind the Altai mountain range. Many micro miners gained skills to prospect new gold sites, and the companies are now using micro miners as their scouts or pathmakers while shifting the blame for mining environmental damages onto "ninja" mining (Ichinkhorloo 2017b:73).

Second, the authors have also discussed how development organizations intervened in micro mining in Mongolia and what they delivered to micro miners and the mismatch of miners' expectation and reality. Given what I found in my earlier research and interviews with "ninja" miners while I was working with SAM project people and Osaka University's GLOCOL researchers in 2011-2014, I would like to suggest an idea that the development organizations constantly change their policies to adjust to new situations. Therefore, they become unable to deliver outcomes planned earlier. For instance, apart from creating a decent workplace through formalization of ninja mining, the SAM project had the ambitious goal to transform ninja miners into entrepreneurs such as small-scale license holding companies or cooperatives like the ones in Colombia and Peru. Until 2012, the SAM project refused to work in Uyanga and Zaamar Sums to avoid project "failure," because these sums were hot spots for illegal activities, disorder, and conflicts between mining companies and ninja miners throughout the 2000s (High 2008). However, the project new management and Swiss Agency for Development and Cooperation in Mongolia changed its policy from a formalization approach to a human rights-based approach to an alternative livelihoods approach in 2005-2018. Within this policy change, the National Human Rights Commission of Mongolia and SAM project conducted human rights assessment in ninja mining areas and documented severe human rights abuses such as killing, sexual assault, detention, beating, and illegal confiscation of ninja miners' properties by company securities and ignored by authorities in Zaamar and Uyanga Sums (Odgerel et al. 2012). This urgent issue demanded rapid policy shift toward conflict resolution through initiating a trilateral agreement that bound mining companies to voluntarily allocate small plots of land to "ninja" miners. This way, the project shifts from one policy to another.

My third comment concerns the authors' claim that "[the ninja miners] have no interest in retaining property relations to land after working it out." It is true that ninja miners do not come back to the land after its resources are exhausted. But depending on the type of mining and size of mineral deposits, micro miners continue to work in one place for up to 20 years and form a special relationship with gold-bearing sites. For example, hard rock micro miners of Bayankhongor aimag have mined Tsagaan tsakhir gold deposits over 20 years, Bornuur micro miners kept working on Sujigt mountain gold deposits in Selenge aimag from 1996 to 2011, and other hard rock miners in Tunkhel village, Selenge aimag have been exploiting a Bor tolgoi gold deposit over 7 years after verbal agreement with Centerra Gold company. Generally, most micro miners are temporary and seasonal, and they do not rely much on gold mining for their livelihoods. However, a few places like hard rock mining sites became permanent, and new relationships are forming around hard rock mining sites. For example, Tsagaan tsakhir local micro miners together organize the local "Ovoonii naadam" celebration and sponsor local government's celebrations and sport events. Most hard rock micro miners work in separate groups called "brigades" (for projects, they are called "partnerships"). Every brigade is sponsored and led by a wealthy and powerful person. In most cases, these local powerful and wealthy people form their own brigades employing people from various places, mainly from local places or nutag. They also possess their own mineshafts and lock them up when they are away. These relationships, looking more entrepreneurial as the SAM project encouraged private property relations, are different from the ones that temporary alluvial micro miners have.

\section{Lhamsuren Munkh-Erdene}

Max Planck Institute for Social Anthropology, Advokatenweg 36, 06114, Halle (Saale), Germany (lkhamsuren@eth.mpg.de). 12 II 18

\section{Different Shades of Neoliberalism}

One fascinates with the stubborn unwillingness and the complete lack of any long-term interest and commitment on the side of those who were engaged in "ninja mining" to "the sustainable artisanal mining," "the occupation," and "the ownership on mining plot." Hence one doubts if their attitude and behavior can, indeed, be said to have "resembled" that of Mongolian mobile pastoralists to their land. Given the lack of commitment, one also wonders if it was really the inability of the development project "to address the fundamental issues of property relations and access to resources" that led to the "enclosing of the goldmining commons" or "de facto public resource" that these "ninja miners" are said to have created. The absence of any longterm commitment including that of ownership seems to have been rooted in the stealthiness of the practice in Mongolia's 
moral and legal property regime on land and natural resources. As the authors outline, land and natural resources, though regulated, had, and to some extent still have, been the commons for centuries in Mongolia. The principle is still enshrined in Mongolia's constitution. ${ }^{25}$ In this moral and legal property regime, the "ninjas" were defectors. They were taking advantage of the commons, and they were keenly aware of this; thus, their activities were ninja-like, that is, stealthy, devious, illicit, and opportunistic. Hence the unwillingness and lack of any longterm commitment. Thus, it is questionable if one can assert what the ninjas did as a creation of "public resource."

The authors seem to claim that land in Mongolia " 'belonged' to the emperor" or "higher authorities." Yet, as recent scholarship demonstrated, land always belonged to ulus or the community, and only the members of the given community had access to it, and the political authorities regulated the access (Atwood 2012). Resourcification seems to be another term for commodification of the commons; however, the larger question involved here is the establishment of the private property regime and the subsequent enclosing of the commons or the public property by private interests. The esteemed name of the procedure is privatization, and its darker side is dispossession, poverty, and polarization. As privatization enclosed the commons, the commoners or community members, or the public, had been dispossessed of their commons. The present property regime on mining was installed in Mongolia with the help of international development agencies as a part of the shock therapy in 1997 with the adoption of the minerals law that allowed private interests to own mineral deposits. By 2010 nearly $17 \%$ of the country's territory was licensed for mineral exploration and exploitation, displacing thousands of herders from their pastures. Today, Mongolia's annual household income per capita is US\$1,466, and one-third of the population lives below the poverty line. The official unemployment rate is about $12 \%$. According to the UNDP's 2015 report, "Richest 20\% of Mongolia consumes 40\% of the total national consumption and the poorest $20 \%$ of Mongolia consumes about 7\%." ${ }^{26}$ A massive dispossession entailed corresponding disentitlement, displacement, and poverty. It also generated a massive income disparity and social polarization, perhaps inevitable casualties of the neoliberal regime. We do not know if divide and rule was ever a sought end of the neoliberal policy. Moreover, there is some darker dimension to it too.

As the primary target of privatization was the commons or "the public property" (ulsyn ömch), branded now with an alienating novel phrase "the state property" (töriin ömch), for instance, Ulaanbaatar's public space became one of the most sought-after targets. Every inch of Ulaanbaatar's public space, from public toilets to playgrounds to schoolyards, had already been privatized. M. Enkhbold, the present speaker of the par-

25. The Constitution of Mongolia, Article 6 (Mongol ulsyn ündsen khuul,' Zurgadugaar züil).

26. United Nations Development Assistance Framework 2017-2021, Mongolia, 2017, p. 19. liament, presided over the privatization of the nation's capital's public space. His declared net worth totals 3 billion tugrik (US $\$ 1.5$ million) whereas his public remuneration averaged about US $\$ 500$ per month over the years. ${ }^{27}$ While running for the Mongolian presidency in 2017, M. Enkhbold publicly declared that he had never engaged in any business activities in his lifetime. ${ }^{28}$ Erdenet Mining Corporation (EMC) is Mongolia's largest "state-owned" enterprise, generating nearly $15 \%$ of the nation's GDP. And, it is the greatest industrial complex that this nation has ever built, and it used to be a Mongolian-Soviet/Russian joint venture. However, in 2016, an unknown Mongolian private entity bought its $49 \%$ from Russia. While the Mongolian president, Ts. Elbegdorj, is credited for facilitating the deal with V. Putin in Tashkent during a meeting of the Shanghai Cooperation Organization, the Mongolian government voluntarily renounced its prerogative in favor of the buyer without the knowledge of the parliament. ${ }^{29}$ The newly elected parliament found the deal illegal and nationalized the $49 \%$. Both the president and the ousted prime minister, Ch. Saikhanbileg, vehemently defended the deal in front of the parliament and the public..$^{30}$ In particular, the president denounced the parliament for "robbing a private property" and claimed that "all the international economic and financial institutions will halt their activities in Mongolia from the moment of the decision, and immediate international economic and financial sanctions will be imposed on Mongolia." ${ }^{{ }_{3} 1}$

Meantime, EMC's 51\% was on trial at the High Court in London because EMC guaranteed and indemnified Just Group LLC, a Mongolian private company, in 2009 for its obligations to South Africa-based Standard Bank. The owner of the Just Group readily confessed that he had forged the guarantee. Questioned about EMC's guarantee on a televised interview, S. Bayar, who was the prime minister when Just borrowed the money from Standard, not only indicated that he has close ties with the owner of the Just Group but also expressed his deep gratitude to him; yet he flatly denied any knowledge of the guarantee. ${ }^{32}$ Bayar's appointee, Ch. Ganzorig, the director of EMC, claimed that he did not issue the guarantee. However, recently the High Court found that EMC indeed guaranteed and indemnified the obligations and ruled EMC to pay more than US\$100 million to Standard Bank. According to Bayar's own admission, his daughters and first ex-wife and wife, together with his close friends, own and run real estate business worth millions of US dollars in the United States. The Panama Papers disclosed that two of his daughters as

27. M. Enkhbold's wealth: http://ikon.mn/visualdata/c/11a6.

28. M.Enkhbold's interview: http://www.dailymotion.com/video/x5khyya.

29. https://thediplomat.com/2016/07/the-mysterious-sale-of-mongolias -erdenet-mine/.

30. Ch. Saikhanbileg's testimony: https://www.youtube.com/watch?v=G 6Sx4uDRyuU.

31. Ts. Elbegdorj's speech: https://www.youtube.com/watch?v=dauwa WA0zEo.

32. S. Bayar's interview: https://www.youtube.com/watch? $\mathrm{v}=\operatorname{tevEB} 4 \mathrm{vx}$ FmE. 
well as his close friends he named in his interviews own offshore accounts. ${ }^{33}$ The Panama Papers also revealed that Bayar's successor as prime minister, S. Batbold, and his brother had offshore entities and accounts too. ${ }^{34}$ Meantime, Mongolia won't receive any dividend from its Oyu Tolgoi mine, a deal that Mongolia signed with Rio Tinto during Bayar's premiership, at least until 2032; instead Mongolia owes Rio Tinto US\$1 billion. S. Bayartsogt, Bayar's finance minister who was one of the signatories of Oyu Tolgoi deal, was also exposed by Offshore Leaks as having an offshore account in Credit Suisse with a deposit amounting to at least 8.2 million euros. ${ }^{35}$ Yet in 2015 the Mongolian parliament legalized all the hidden wealth, including that of politicians and government officials. The law not only pardoned those who disclosed their hidden wealth of all the criminal charges (or legal liabilities) but also forgave their tax debt. ${ }^{36}$ "Ninja mining" was a practice of this sort, essentially, an opportunistic looting or pillaging of the commons, clearly, out of desperation and whatnot. Yet, the "ninja miners" and the development project did not have the power to legalize the illicit practice of "ninja mining" into sustainable artisanal mining. Whereas "ninja miners" were just an aggregate of law-breaking commoners, the development project, obviously, lacked the leverage that the International Monetary Fund, the Word Bank, or the Asian Development Bank had enjoyed. Moreover, though there might have been some sympathy, the public generally disapproved of their actions. In addition, their actions, as the authors show, were conflicting with organized, powerful private corporate interests. As for the Mongolian authorities, legalizing of their activities was to become a precedent of condoning looting publicly. Oligarchy and kleptocracy were never a stated aim of any neoliberal policy. In fact, we do not know if its designers foresaw oligarchy and kleptocracy as its inevitable ills, and if they did condone it to justify their higher, noble ends. We also do not know if they ever foresaw the possibility that the oligarchy and kleptocracy could capture the state, and through it make otherwise "looting of the public" legal and normal. Oligarchic and kleptocratic regimes that we find in many of the postcommunist countries are essentially products of the neoliberal shock therapy. Neoliberal privatization created an environment where communist nomenklatura not

33. Offshore accounts and entities of the daughters of S. Bayar: https:// offshoreleaks.icij.org/search?utf8 $=\% \mathrm{E} 2 \% 9 \mathrm{C} \% 93 \& \mathrm{q}=$ Bayar\&e $=$ \& commit $=$ Search.

34. S. Batbold and his brother's offshore entity and account: https:// offshoreleaks.icij.org/stories/sukhbaataryn-batbold; https://offshoreleaks.icij .org/nodes/12182099.

35. S. Bayartsogt's offshore account: https://offshoreleaks.icij.org/nodes /178152. See also a Reuters report on the transfer of 8.2 million euros to S. Bayartsogt's account (https://www.reuters.com/article/us-swiss-rio-tinto -plc-mongolia/swiss-seize-bank-accounts-amid-probe-linked-to-rio-tinto -mongolia-mine-idUSKBN1GV1AG) and Swiss Court ruling on March 2, 2018 (https://www.bger.ch/ext/eurospider/live/de/php/aza/http/index.php ?highlight_docid = aza\%3A\%2F\%2Faza\%3A\%2F\%2F02-03-2018-1B_258 -2017\&lang = de\&zoom = \&type = show_document).

36. Ediin zasgiin il tod baidlyg demjikh tukhai: http://www.legalinfo $. \mathrm{mn} / \mathrm{law} /$ details/11269. only looted the commons and the public property and emerged as an oligarchy, but also turned the communist regimes into kleptocratic regimes.

Moreover, evidence shows that while international development agencies were helping Mongolia to establish a free market economy, behind the curtain powerful international corporate mining interests were lobbying "Canada, the U.S., British, Japanese, Australian and German efforts to encourage (cajole, harangue, etc.) the Government of Mongolia into staying out of the mining business." ${ }^{37}$ Private ownership of land and natural resources had been not normal in Mongolia for its entire existence, and the government always regulated access to the commons. Defections from the commons by commoners were and are, perhaps, always present; as such, it can be accepted as normality, albeit inconvenient. However, what is not normal is that the institution of which the primary raison d'être is to curtail defections serves for defections of those who captured the state. As Ulaanbaatar's space, or EMC, or the legalizing of the hidden wealth of the kleptocracy illustrate, Mongolia's "political and business elite" use Mongolian government as a tool for takeover of the commons and the public property. Neoliberalism not only normalized private ownership in Mongolia but also reduced Mongolian government to a tool to protect and advance private corporate interests at the expense of the public. Either its ills or the shortcomings of the designers, the neoliberal policy not only allowed the nomenklatura to loot the country's commons and the public property but also helped to create a kleptocratic regime. We do not know how sustainable this new normality can be. Ironically, when Yu. Tsedenbal, who presided over Mongolia for 4 decades, retired in 1984, he owned no apartment and had only 6,000 tugrik (US $\$ 1,635$ by official fixed rate, or US $\$ 300$ by "black market" rate) in his savings account. ${ }^{38}$ And that was perfectly normal back then.

\section{Natalia Ryzhova}

Economic Research Institute, Far Eastern Branch of Russian Academy of Science, 153 Tikhookeanskaya Street, Khabarovsk 680042, Russia (ryzhova@ecrin.ru).25 II 18

Each time I read papers on the survival of "ordinary people" from the Russian, Mongolian, or Kyrgyz remote areas, of those who were born in the world of socialism and had to adapt to the world of capitalism, I ask myself the same questions. If there was an opportunity for the residents of small towns and villages to have conditions for smoother, painless transition and for sustainable livelihoods, what resources, rules, or relations could guarantee their worthy adaptation to the new reality? Each time

37. "Visiting Canadian trade minister advises against state ownership of natural resources," US Embassy cable, January 11, 2008. https://wikileaks .org/plusd/cables/08ULAANBAATAR15_a.html.

38. Speech delivered by J. Munkhbat, chief cabinet secretary, on Yu. Tsedenbal's hundredth anniversary: http://www.ugluu.mn/225228.html. 
the answer is hopelessly negative: no opportunities, rules, resources, or relations could save those people who make up most of the population of Russia or Mongolia from the crisis, and from what Munkherdene and Sneath called a "scavenger economy."

The article "Enclosing the Gold-Mining Commons of Mongolia" not only demonstrates how the transition to the market made people turn to informal gold mining but also explores the reasons for the desperate attempts to solve the problem of the poor through the usual, "prescribed" neoliberal developmental reasoning. In the article, the Sustainable Artisanal Mining Project (SAM project) acts as another hopeless attempt to break poverty bonds. The SAM project identifies the ninja "problem" in terms of a lack of formalization, dearth of jobs, and insufficient training of locals engaged in informal activities. The problem of poverty in the SAM project, like in many other similar ones explored by anthropologists, has been narrowed to the technical issue of training the poor, providing them with legal papers, methods of self-organization, and other simple solutions. The despair of the situation is that the SAM project did not raise, did not solve, and largely could not address the issue of property relations and access to resources that lies behind the ninja "problem." The reason why the SAM project failed and, moreover, why it had to fail, is that it was designed to enforce new property regimes that were supposed to exclude or at least significantly limit informal gold miners from access to resources.

The article by Munkherdene and Sneath does not raise the question of successfulness of market reforms in Mongolia or other countries. Nevertheless, the authors infer that not only that "transforming opportunistic resource exploitation into sustainable livelihoods remains as elusive as ever," but also that the overall success of reforms remains an illusion - at least if one focuses on the success of the reform for the "ordinary people." This illusion is obvious for the millions of poor people living not only in Mongolia, but also in Russia or the Ukrainian outback, who informally mine gold or coal, fish, or gather wild plants. This illusion is obvious if one is aware that before the transition those people worked for collective farms, factories, or plants, and, therefore, had a regular income. Largely it does not matter for them whether those factories and farms had been effective or not. More important is that they had been paid a monthly salary and had a living standard similar to a resident of "a big city." This illusion is obvious when one realizes the daily deadly risk of mercury poisoning in artisanal gold mining, the collapse of a self-made coal mine, or the clutches of a hungry bear. This illusion is obvious when one realizes that people living even in small towns, and especially in villages, had had access to medical care. Nowadays they need to go several hundred kilometers off-road to get to the hospital, but before - and people remember it well - the road had been of better quality and there used to be regular buses. This illusion is obvious if one keeps in mind that, before the transition, compulsory education had been accessible for children of those people. Nowadays they have to get to school by the same broken road. And hardly did they agree that the "old" education did not suppose the devel- opment of critical thinking, but, on the contrary, it made them believe in "our better tomorrow."

In other words, if one uses Ferguson's thought and considers the transition to the market as a big developmental project, then one should admit that this project definitely failed to help poor people. Even more, the market transition caused many "ordinary people" to become the real poor, those whose living standards are visibly different from the living standards of the rich owning resources. Why did it happen? Without raising the question of why the market reforms failed to help many "ordinary people," the article by Munkherdene and Sneath nevertheless offers an analytical tool for answering the question. They do so by studying the process of "resourcification" (term implemented by High [2010]), or the transformation of items into resources, into "sources of potential wealth." Munkherdene and Sneath explore resourcification of the land containing gold and of geological funds. They showed, for example, that although geologists and former mine workers had knowledge of how to transform geological funds into "sources of potential wealth," this activity was shortly identified as illegal. Thus, an exclusion of them from the access to resources was only a matter of time.

All market reforms, in a sense, are a redefinition, the transition of non-resources into resources. Transition required not only legal privatization, but also awareness and public acceptance of resourcification. Some resources were rather ready for such a transition (e.g., apartments or factories), and some were rather not, such as land or public education. Accordingly, reinvention of the poor in postsocialist countries was a process of preventing "ordinary people" from becoming resourceful, complemented by the process of discursively identifying any attempts to participate in resourcification in terms of illegality. On the contrary, "Communist nomenklatura successfully reinvented themselves as an oligarchic plutocracy" precisely through guaranteed participation in both resourcification and discursive definition of this process in legal terms.

Following the research logic of Ferguson (1994), the question "Why did it happen?" can be replaced with the questions "What has been achieved? What was the result of the neoliberal reforms in the postsocialist countries?" The answer is, as I see it and as the article by Munkherdene and Sneath suggests to us: reforms and privatization made usual while unjust state of affairs to happen. There are poor and rich, and the rising gap between them is attributed to the access to resources. However, unlike Ferguson's outcomes, well known to every student of the anthropology of development, the net effect of the marketreform project was not the depoliticization of the issue of resource allocation. On the contrary, the distribution of resources in postsocialist countries underwent thorough politicization (such issues as freedom, democracy, property rights, etc.). But this politicization - not the same politicization as Ferguson asked for-led to the same end. The poor have to survive because they do not have access to resources.

Next year, Germany will be celebrating the thirtieth anniversary of the Berlin Wall collapse. In 2018, 27 years have passed since the Union of Soviet Socialist Republics ceased to exist, and 26 years have passed since the adoption of the new 
constitution of Mongolia and the beginning of the state property privatization there. More than a quarter of a century is sufficient enough to draw conclusions, albeit intermediate, to reflect on the results and make assumptions about the further development of the countries of the so-called former socialist camp. Reflecting on the results of 25 years of reforms is not sufficient to evaluate the socioeconomic consequences of the reforms for ordinary people. After all, not only the economy caused socioeconomic transformations both in Mongolia and in other socialist countries. Preventing the "Cold War" and reducing the unnecessary costs associated with it, refusal of political repressions, and recognition of the rights and freedoms of citizens were among those dignified causes that made sense of the reforms and encouraged ordinary people to actively support the market transition. However, now many of them feel cheated. Moreover, here and there we see a rollback to previous models, ideas, and ideals. It is enough to open up any media resources to doubt that the world has overcome the problem of the Cold War.

\section{Eric Thrift}

Department of Anthropology, University of Winnipeg,

515 Portage Avenue, Winnipeg MB R3B 2E9, Canada

(e.thrift@uwinnipeg.ca).25 II 18

In their ethnographic critique of the SAM project, Munkherdene and Sneath evoke a number of recognizable themes from the anthropology of development: mismatches between project beneficiaries' expectations and what the development project is able to provide, conflicts arising from the project's misreading of "community" solidarities, and an overall elision of politics. The "need for formalization" at the core of this project is a clear example of what $\operatorname{Li}(2007,2011)$ calls "rendering technical" - establishing a circumscribed, legible group of stakeholders (micro miners) whose needs can be mapped to an expert-driven technical intervention (SAM). Within this familiar critical terrain, the authors usefully draw attention to property relations as a focus of analysis, evoking areas for greater theorization on how alternative "property regimes" may be discursively generated or undermined by international projects and their participants.

I suspect we all might agree that SDC has brought about tangible gains for some resource users. As noted in this article, members of formalized micro mining partnerships established under the SAM project benefit from new political representation, legal recognition of their right to access mineral resources, improved workplace safety, and access to health and social security benefits (SDC 2012a, 2016). This project has additionally contributed to shifting public and policy-maker opinion somewhat in favor of small-scale miners. At the end of their article, however, Munkherdene and Sneath suggest that things have begun to unravel: as the SAM project winds down, the micro miners shift their attention to other activities - and toward other development projects to "mine." What went wrong?
On one level we might simply infer an excessively zealous commitment by project staff to maintaining positive spin, leading to absurdly counterfactual narratives such as the one celebrating the "success" of the dissolved Enkhmönkh NGO. Looking more deeply, however, we detect important gaps between the project's representations and the realities lived by project participants. For small-scale miners, is gold or the SAM project the more valued resource? Do the miners join partnerships to secure tenure of common-property resources, or do they simply use formalized property rights as a mechanism for protecting an open-access regime? Most importantly, do they even aspire to view themselves as miners in occupational terms?

This last question seems to reach at the core of the issue, because the professionalized "artisanal and small-scale miner" is a role performed within the context of the project, rather than an identity that precedes the SDC intervention. The formalization logic is predicated on an assumption that informal mining, driven by poverty shocks or by opportunism, is a temporary arrangement with the potential to give rise to "communities" who engage in permanent or seasonal "community mining" (SDC 2012a: 13). For this to occur, miners must develop occupational solidarity - that is, they must identify as miners, rather than as people who seasonally or occasionally "go to the goldfields" (altand yavakh) as part of a diversified livelihood strategy. Project literature thus meticulously describes smallscale mining as a distinct occupational sector, encompassing " $20 \%$ of the rural workforce" and constituting the "highest employer in the mining sector" (Singo 2012:5). Miners are portrayed as both entrepreneurial and community oriented, as demonstrated by the "success story" of their investment in a mercury-free processing plant at Bornuur (Singo 2012). These representations contradict the reality of gold miners as a diverse range of actors who, in many cases, cannot benefit from formalization: students trying to earn their tuition during the summer holiday, small-scale herders or underpaid civil servants looking for supplementary cash income, and so on.

Munkherdene and Sneath thus invite us to think about the "differences between the development project representation of ninja mining and the understandings of those actually engaged in the practice." This brings to mind the question Robert Chambers (1997) put to development professionals, "Whose reality counts?" reflecting his contention that development professionals and the poor live in different realities - the one grounded in standardization and measurability, the other in local experience, diversity, holism, and complexity. I think it may be most helpful to think about these realities less in terms of ontological difference, however, than in terms of situated ways of "doing," in the performative sense. For project participants, being an entrepreneurial "small-scale or artisanal miner" is a matter of performing a role, partly as a means of accessing project resources. It is within this context that we observe the translation of local needs — often material—into forms that are "legitimate" in the language of the project (Mosse 2001).

The "rendering technical" of the development project can also be viewed as a performative exercise, to the extent that the 
ASM economy and its stakeholders are produced by the very action of being discussed. Appel (2017) has described such performative discourse, productive of "national economies" and similar imaginaries, as occupying an "as-if" space between the world and its representations. In the case that Munkherdene and Sneath describe, both "property" and "resources" might be seen as inhabiting this same space. We see that claims to various rights over resources such as land and gold have been asserted on the basis of customary use, place-based community ("nutagism"), the labor of extraction, or a priori possession by the state of alienable property rights. These claims are facilitated by what the authors call a neoliberal "private property regime," which we might take as establishing the groundwork for the "as-if" of property as something that can naturally be owned. This space of contingent and contested resource access is divisive, as Munkherdene and Sneath assert in their conclusion, but it is also a productive one, in which results created "on paper" find tangible - if sometimes unexpected-purpose in the real world.

\section{Sören Urbansky}

German Historical Institute, 1607 New Hampshire Avenue Northwest, Washington, DC 20009, USA (urbansky@ghi-dc.org). 13 II 18

This paper, focusing on "ninja gold mining" in postsocialist Mongolia, provides an instructive picture of the wider transformation of political economy in this landlocked state sandwiched between China and Russia. What struck me most while reading this insightful and brilliantly written article by G. Munkherdene and David Sneath are the historical parallels with unauthorized small-scale gold mining in other parts of Inner Asia. Responding to this fascinating piece of research, I will focus on historical connections to an earlier "gold rush" during the late nineteenth century that seem to remain somewhat underdeveloped.

About a century before Soviet and Mongolian geologists found significant alluvial gold deposits in Mongolia in the 1970s and 1980s, the discovery of gold had triggered a rush in the still rather porous the Sino-Russian borderlands, in particular to Eastern Transbaikalia and the Amur Basin. In those years thousands of fortune seekers, peasants, and drifters who went to try their luck came from neighboring regions and other areas of Russia and China, and some even from abroad. Most famously perhaps was the "Zheltuga Republic" in the northernmost part of Manchuria in the 1880s (Gamsa 2003; Zatsepine 2017:62-67).

Gold mining became a significant economic sector in both the Chinese and the Russian borderlands. By the turn of the century, dozens of mines operated in northern Heilongjiang Province in the vicinity of Heihe and in northern Hulunbei'er, owned mainly by Chinese, Russian, British, and American entrepreneurs. Mining of this precious metal loomed even more important on the Russian side. In Transbaikalia alone there were about 150 private and official gold mines, almost half of them near the lower and middle reaches of the Argun (Kommisiia 1901:140-148; Kormazov 1927; Torgashev 1927). Although the exploitation of gold in Transbaikalia had already peaked in 1901, the number of gold diggers increased over the following years. The majority of the 17,210 workers who would be employed in the goldfields of Transbaikalia in 1909 came from China (Obzor 1911). A significant amount of the gold was trafficked from Russia to China-inverting the flow of other contraband. This remained unchanged until the consolidation of Soviet rule, when the share of Chinese subjects in the Soviet goldfields began to fall and then declined considerably with the deportation of Chinese subjects from the USSR during the mid1930s (Larin 2009:119-140).

A comparison of the prerevolutionary Sino-Russian with the postsocialist Mongolian "gold rush" reveals a striking degree of convergence: the nature of private gold mining in these rural and remote regions was highly fluid in both cases. The number of those attracted by the precious metal was significant, yet it varied from season to season and is impossible to quantify. The bulk of people engaged in digging stemmed from rather poorer population strata and were neither full-time miners nor professionals. The work in the goldfields was primarily seasonal due to the harsh climate and other activities miners were involved in such as herding, farming, petty trading, and so forth. These highly volatile qualities are reflected in the nature of the dwellings around the mines. Building structure was temporary. Housing, shops, and taverns were densely populated during the summer months and nearly abandoned during the winters. In both cases, albeit for different reasons, a low moral authority of the state and its inability to enforce laws facilitated the unsanctioned mining activities. Whereas at the turn of the twentieth century, state bureaucracy of Russian and Chinese empires at their shared periphery was still frail with weak allegiances of the people, the collapse of state socialism had undermined the authority and executing powers in 1990s Mongolia. The most important common feature however is, perhaps, a similar notion of land ownership in which the private ownership of land in the current commercial sense does not exist and the landscape is seen as public in some sense.

Obviously, differences between the prerevolutionary and postsocialist settings exist. While in turn-of-the-twenty-firstcentury Mongolia micro mining appears to be a national phenomenon with Mongols from surrounding areas involved, the late nineteenth-century communities of gold miners in the Russo-Chinese borderland were far traveled and of various ethnic and national backgrounds. This contrast can be explained by the formation and maturation of the nation-state.

Both the often-secret Sino-Russian mines on the Amur and its tributaries as well as the "ninja mines" in central Mongolia were short-lived. They disappeared when vertical power was (re)established and state monopoly or, in the Mongol case, global mining companies entered the market. Increasingly, legitimate owners enforced their exclusive legal rights, and executive organs supported their claims by being assertive in punishments of illicit gold-mining operations. 


\section{Reply}

We are very grateful to all the contributors for the range and depth of reflection that they have added to our work. We cannot address all the many perceptive points that they raise here, but we would like to offer some comment on three broad themes.

First, there is the question of the how the story of "ninja" mining informs our understanding of Mongolia's wider capitalist political economy, and the results of neoliberal reform. As Naran Bilik notes, in Polanyian terms the scavenger economy appears to be a symptom of a society placed at the mercy of market forces. But it is also clearly an outcome of the particular policies of the Mongolian state, which Lhamsuren MunkhErdene describes as the targeting of public property - including every inch of public space in Ulaanbaatar - so that the business elite could convert it into private wealth. This reminds us of Harvey's (2005:160) point, that what Marx termed "primitive accumulation" is not a completed historical phase of capitalism but an ongoing process that busily searches out new assets for privatization. But this could also be seen as a form of scavenging, albeit on a grand scale, the seizing of whatever resources appear as available. At a time when the nascent super-rich were busy mining private wealth from the assets that the state did control, tens of thousands of ordinary people set about mining wealth from assets that the state could not fully secure.

The overall results of market reforms in Mongolia were not, as Natalia Ryzhova remarks, the main focus of our paper. But as several discussants suggest, successive postsocialist governments failed to seriously reduce mass poverty. About a third of the population were living below the poverty line in the late 1990s and, although the rate has fluctuated year on year, roughly the same proportion have been stuck there ever since. Poverty reached an estimated 39\% in 2009-2010 (Gan-Ochir and Ariun-Erdene 2017:17), for example, and although this figure fell to $22 \%$ in 2014 , the 2016 estimate placed almost $30 \%$ of the population below the poverty line-living on US\$60 a month or less. ${ }^{39}$ The volatility of the poverty rate tells its own story, indicating the large number of people living precariously close to the poverty line and liable to drop below it when the economy slows. This brings us to Lars Højer's point regarding the implicit ideological work carried out by development projects that might be said, following Ferguson (1990), to help reproduce existing property relations. The inability of the SAM project to achieve its ambitious goals was, no doubt, partly the result of the sort of policy inconsistency that Byambabaatar Ichinkhorloo describes. In part it also reflected the sort of logics implicit in the notions of "community development" that Eric Thrift points to, in which potentially solidary occupational groups are misleadingly pictured as a natural feature of the economy, ready to benefit from

39. World Bank, http://www.worldbank.org/en/news/press-release/2017 /10/17/2016-poverty-rate-in-mongolia-estimated-at-296-percent. formalization. The broader context, however, was that the project felt bound to work within the existing property regime, the "new normality," as Lhamsuren Munkh-Erdene puts it, that entailed the exclusive private ownership of almost all major sources of wealth in the country. It seems to us that this placed the most severe limits upon the extent to which the project could deliver well-paid and stable employment for micro miners.

Second, we turn to the question raised by Gregory Delaplace - what counts as a resource in Mongolia? The answers, we feel, are likely to be historically determined, a result of changing regimes of property and value. As Ryzhova points out, the market reforms were themselves a process of redefinition, both in legal terms and in public perception, which identified new sources of potential wealth. We appreciate Delaplace's distinction between the hidden and the open, and the notion that "making visible" is central to the processes of recognition and resourcification. Here the historical perspectives that Bumochir Dulam and Sören Urbansky introduce are particularly revealing. As Bumochir shows, some sorts of mineral resources were recognized (as potential sources of wealth for outsiders) in Qing times, because "gold patrols" were instituted to guard against foreign gold miners, and the Bogd Khan administration also tried to raise funds by recognizing minerals as natural resources and commodifying them. Interestingly, Sodbaatar's (2013) study of the historical materials on illegal gold mining and precious stone collection show that it was not only foreigners who might be culprits, but local herders and even lamas.

It may be, then, that official normativity regarding what counts as a resource, and who is entitled to it, is never uniform and total, and that any property regime is likely to have what Lhamsuren Munkh-Erdene called "defectors" - those who take the "things that are not for the taking" as Delaplace puts it. The scale and character of this defection seems bound to reflect the historical particularities of the age, the levels of want, and the intensity and extent of dominant normativity. In this respect the parallels between the late nineteenth-century gold rush in the Sino-Soviet borderlands described by Urbansky and contemporary Mongolian micro mining are intriguing. Not only are the shifting populations and seasonal patterns of informal work strikingly comparable, but the historical demise of the gold rush is revealing. The defectors from the old czarist property regime for land were eventually overtaken by the Bolshevik state; wealth was returned to the hands of the powerful, albeit Soviet rather than corporate.

Lastly, there is the question of how to characterize the utilization of land in the micro-mining gold rush, and to what extent this has anything to do with the longue durée of Mongolian history. We might doubt, as Lhamsuren Munkh-Erdene does, whether "ninja" attitudes to land were really informed by mobile pastoralism, particularly in light of the way in which the contemporary practices resemble those found in the nineteenthcentury gold rush described by Urbansky, which involved Russians and Chinese miners, rather than Mongols. In both epochs, it seems, and independent of any particular mobile or sedentary lifestyle, very similar patterns emerged. And as Højer perceptively points out, we could as well draw parallels between the micro miners and multinational companies, because they also 
"extract and move on," albeit on a vaster scale. Indeed, we would certainly agree that there is no need to assume some sort of distinctive cultural logic at work, based on nomadism, shamanism, Buddhism, or any of the other standard terms of debate. But when it comes to the presence of various norms, values, and notions in public culture, it seems to us that we are bound to look to history and historical processes, some of them long term, to account for them. So contemporary Mongolian attitudes to land reflect the particularities of a path-dependent history that includes the installation and superimposition of various normative schemas, including religious and secular cosmologies, aesthetic sensibilities, land-use practices, and property regimes. The emphasis placed upon Mongolia's distinctive history and "nomadic civilization" (nü̈̈dliin irgenshil) in twentieth-century public culture (see Tsetsentsolmon 2014) meant that, as Naran Bilik notes, an examination of the influence of the concept of nomadism is not an act of pure imagination. Rather, it involves an excavation of the history of ideas and their practical expression (if any).

Instead of regarding culture as some sort of integrated system, which produces characteristic behavior as a result of its own internal logics and character, we can treat it as a repertoire of common meanings, representations, and practices - including "situated ways of doing" in Thrift's neat phrase. This provides actors with the cultural resources to navigate their social worlds and to make various claims upon them. In this respect we found Bumochir's historically informed perspective particularly helpful because he describes attitudes to land in terms of contestation, so that a multiplicity of claims may be made on the basis of different normative frameworks, be they the authority of local government, the constitutional codes of the nation-state, or the spiritual and religious frames termed shamanic or Buddhist. Of course, claims that it is (or is not) permissible to take mineral resources may not be recognized by the state or other citizens. On this point Lhamsuren Munkh-Erdene argues that the gold rush entailed "taking advantage" of the commons and did not lead to the creation of a recognized public resource as such. We would not disagree, and used the term "de facto public resource" to distinguish it from a de jure or normative form of public property. Our point was that in practical terms members of the public could gain access to the goldfields, and a large number of them did so.

This brings us to Højer's point that an analysis in terms of "privatization," "enclosure," "commons," and so on invites further reflection as to the underlying assumptions that these concepts bring with them. We agree, because although these encompassing terms can serve heuristically to stimulate comparison and the recognition of resemblance, they might also be candidates for inclusion in Appel's (2017) category of "as-if" performative discourse described by Thrift, along with "property" and "resources." Of course semantic exploration of all these terms is beyond the scope of any given paper, but we can certainly try to examine the extent to which the actual practices of micro miners resemble the analytical concepts. Here, Byambabaatar's observations are particularly revealing. The hard rock micro miners he describes in Bayankhongor and Selenge have tried to establish longer-term exclusive use-rights, organized by local wealthy and powerful persons into production "brigades" (a term reminiscent of the old collectives and state enterprises); they lock up their mineshafts to keep others out. This clearly reflects the nature of the hard rock deposits in question, which take longer to mine out. But it also demonstrates a more general point - within the wider commons category, the actual use of resources is bound to be exclusive to some degree. In the pastoral commons (and this is not to imply cultural connection), winter pastures are generally kept for exclusive use, and even in entirely open-access rangeland any given blade of grass could be said to be "monopolized" by the first animal that eats it, not shared out between those theoretically eligible.

Many common-pool resources put people in potentially rivalrous positions, be they car parking places or pavement space for begging, because the resource units they provide cannot be used by all the would-be appropriators at the same time (Ostrom 1990:31). This is a well-recognized feature of common resource systems. As we described, most micro-mining teams were strongly concerned with gaining and keeping access to goldbearing land. Placed outside the legal structure of the state, those engaged in the actual extraction of wealth seek to turn their particular small patch into, in Højer's wry phrase, the "not-so-de-facto commons." So, like the big mining teams who evict weaker rival groups by force, the hard rock miners who lock up their shafts try to create something like exclusive private rights over the resources in question, at least for as long as it is useful to them. These are aims and goals - understandable enough since the normalization of private ownership in Mongolia noted by Lhamsuren Munkh-Erdene. But until and unless the users gain legal ownership and public recognition, their exclusive use will remain insecure and liable to future challenge. Disputes of this type are found in the region of Khövsgöl mentioned by Byambabaatar, where the Centerra Gold company has expanded its land claims to encompass areas where "ninjas" had been working. Centerra's claims to exclusive use of the land were challenged on the grounds that, under the amended Law on Minerals, the local government had granted legitimate access to micro-mining partnerships made up of district residents, many of them within the partnership structure created by the SAM project. And of course, where companies were unable to enforce exclusive rights to land ("enclosure"), some micro miners dared to work it for themselves, thus "commoning the enclosed resources again," as Byambabaatar put it. Other exclusionary rights, such as those imposed by the state in conservation areas, may also be ignored by the bold. It is worth noting, however, that the micro mining in the Khövsgöl Lake National Conservation Park and Great Gobi Strictly Protected Area that was reported in the past has, to our knowledge, all but disappeared. In general it seems that state power, which can serve as a vehicle for private and corporate interests, is catching up with the micro-mining commoners, just as the Soviet variety did in the Sino-Russian goldfields about a century ago.

-G. Munkherdene and David Sneath 


\section{References Cited}

Appel, Hannah. 2017. Toward an ethnography of the national economy. Cultural Anthropology 32(2):294-322. [ET]

Appel, Peter W. Uitterdijk. 2005. Small-scale mining in Mongolia-a survey carried out in 2004. Danmarks og Grønlands Geologiske Undersøgelse Rapport 2005/4. https://unites.uqam.ca/gmf/globalmercuryforum/pages/members /europe/Denmark/files_peter_appel/2005-4\%20PA\%20\%20Small\%20scale \%20mining.pdf.

Asia Foundation. 2006. Communities partner to protect environment and livelihoods. Mongolian Highlight. https://asiafoundation.org/resources/pdfs /MGmining.pdf

Atwood, Christopher. 2012. Banner, otog, thousand: appanage communities as the basic unit of traditional Mongolian society. Mongolian Studies 34:176. [LM-E]

Banzragch, C. 2004. Altain haruulyn tuhaid [About the patrols of the Altai]. In Manjiin erhsheeliin üyiin Mongol [Mongolia in the times of the Qing occupation]. J. Boldbaatar, ed. Pp. 86-92. Ulaanbaatar: Orbis. [BD]

Batsaikhan, O. 2009. Bogdo Jebtsundamba Khutukhtu, the last king of Mongolia: Mongolia's national revolution of 1911. Ulaanbaatar: Admon. [BD]

Bebbington, Anthony. 2012. Conclusions. In Social conflict, economic development and the extractive industry: evidence from South America. Anthony Bebbington, ed. Pp. 216-228. London: Routledge. [BD]

Boltanski, Luc, and Laurent Thévenot. 2006 (1991). On justification: economies of worth. Princeton, NJ: Princeton University Press. [GD]

Bonilla, Lauren. 2016. Extractive infrastructures: social, environmental, and institutional change in resource-rich Mongolia. PhD dissertation, Clark University, Worcester, MA. [BD]

Brook, Pete. 2015. Inside the dangerous world of amateur "ninja" gold miners. Wired, January 29. http://www.wired.com/2015/01/alvaro-laiz-ninjas-gold-rush -in-mongolia/.

Bruun, Ole, and Ole Odgaard. 1996. A society and economy in transition. In Mongolia in transition: new patterns, new challenges. O. Bruun and $\mathrm{O}$ Odgaard, eds. Pp. 23-41. Richmond: Curzon.

Byambabaatar, I. 2016. Mongolia's diverse economy: survival assemblages in Mongolia's capitalist advancement. Paper presented at the Mongolian-Made Capitalism conference, National University of Mongolia, Ulaanbaatar, November 16 .

Chabros, Krystyna. 1992. Beckoning fortune: a study of the Mongolian Dalalga ritual. Wiesbaden: Harrassowitz. [GD]

Chambers, Robert. 1997. Whose reality counts? putting the first last. London: Intermediate Technology. [ET]

Creed, Gerald. 2006. Reconsidering community. In The seductions of com munity: emancipations, oppressions, quandaries. G. Creed, ed. Pp. 3-22. Oxford: Currey.

Davis, Mike. 2004. Planet of slums: urban involution and the informal proletariat. New Left Review 26:5-34

Delaplace, Gregory. 2012. Neighbours and their ruins: remembering foreign presences in Mongolia. In Frontier encounters: knowledge and practice at the Russian, Chinese, and Mongolian border. F. Billé, G. Delaplace, and C. Humphrey, eds. Pp. 211-233. Cambridge: Open Book. [GD

Descola, Philippe, and Gísli Pálsson. 1996. Nature and society: introduction. In Nature and society, anthropological perspectives. P. Descola and G. Pálsson, eds. Pp. 1-21. London: Routledge.

Empson, Rebecca. 2011. Harnessing fortune: personhood, memory and place in Mongolia. Oxford: Oxford University Press. [GD]

Escobar, Arturo. 1994. Encountering development: the making and unmaking of the third world. Princeton, NJ: Princeton University Press.

. 2006. Difference and conflict in the struggle over natural resources: a political ecology framework. Development 49(3):6-13.

Ferguson, J. 1990. The anti-politics machine: “development," depoliticization, and bureaucratic power in Lesotho. Minneapolis: University of Minnesota Press. [LH]

- 1994. Anti-politics machine: "development" and bureaucratic power in Lesotho. Cambridge: Cambridge University Press.

Gamsa, Mark. 2003. California on the Amur, or the "Zheltuga Republic" in Manchuria (1883-86). Slavonic and East European Review 81(2):236-266. [SU]

Gan-Ochir, D., and B. Ariun-Erdene. 2017. Implications of economic growth, poverty and inequality in Mongolia over the period of 2008-2012. Northeast Asian Economic Review 5(2):15-29.

Geertz, Clifford. 2000. Available light: anthropological reflections on philosophical topics. Kindle edition. Princeton, NJ: Princeton University Press. [NB]
Gibson-Graham, J. K. J. Cameron, and S. Healy. 2016. Commoning as a postcapitalist politics. In Releasing the commons: rethinking the futures of the commons. A. Amin and P. Howell, eds. Pp. 192-212. London: Routledge. [BI] Goldman, Marshall. 2003. The piratization of Russia: Russian reform goes awry. London: Routledge.

Grayson, R., W. Murray, U. Tuul, T. Delgertsoo, and B. Tumenbayar. 2003. Ninja gold miners of Mongolia: assistance to policy formation for the informal gold mining sub-sector in Mongolia. Ulaanbaatar: Mongolian Business Development Agency, Canada Fund Mongolia.

Grayson, Robin. 2007. Anatomy of the people's gold rush in modern Mongolia. World Placer Journal 7:1-66.

Griffin, K. 1995. Economic strategy during the transition. In Poverty and the transition to a market economy in Mongolia. K. Griffin, ed. Pp. 1-26. New York: St Martin's.

Harvey, David. 2005. A brief history of neoliberalism. Oxford: Oxford University Press.

Herzfeld, Michael. 2014. Intangible delicacies: production and embarrassment in international settings. Ethnologies 36(1):47-61. [NB]

Hetherington, Kregg. 2009. Privatizing the private in rural Paraguay: precarious lots and the materiality of rights. American Ethnologist 36(2):224-241.

High, Holly. 2010. Laos: crisis and resource contestation. Southeast Asian Affairs 2010:153-161.

High, Mette M. 2008. Dangerous fortunes: an anthropological study of the Mongolian informal gold mining economy. PhD dissertation, University of Cambridge.

- 2013. Cosmologies of freedom and Buddhist self-transformation in the Mongolian gold rush. Lournal of the Royal Anthropological Institute 19(4):753-770.

. 2016. A question of ethics: the creative orthodoxy of Buddhist monks in the Mongolian gold rush. Ethnos 3(1):80-99.

. 2017. Fear and fortune: spirit worlds and emerging economies in the Mongolian gold rush. Ithaca, NY: Cornell University Press.

Højer, Lars, and Morten Axel Pedersen. Forthcoming. Urban hunters: dealing and dreaming in times of transition. New Haven, CT: Yale University Press. [LH]

Humphrey, Caroline. 2010. Foreword. In Mette High: Ayultai khishig: Mon goliin alban bus altnii uurkhain ediin zasag dakhi khorongo ba etsegchlel [Dangerous fortunes: wealth and patriarchy in the Mongolian informal gold mining economy]. Bumochir Dulam, ed. Ulaanbaatar: Admon.

Ichinkhorloo, B. 2017a. Environment as commodity and shield: reshaping herders' collective identity in Mongolia. In Pastoralist livelihoods in Asian drylands: environment, governance and risk. A. Ahearn, T. Sternberg, and A. Hahn, eds. Pp. 41-70. Winwick: White Horse. [BI]

. 2017b. Khugjil ood khutluulj bui bidnii zam: Uul uurkhai baigal orchin [Road paved for development: mining and environment in Mongolia]. In Zam: Mongoliin tald zurah zam [Road: the future painted on Mongolian steppe]. Cetsenkhuu and Byambakhorol, eds. Pp. 52-82. Ulaanbaatar: Soyombo. $[\mathrm{BI}]$

Irvine, Richard. 2018. Seeing environmental violence in deep time: perspectives from contemporary Mongolian literature and music. Environmental $\mathrm{Hu}$ manities 10(1):257-272. [GD]

Karpoff, Boris S., and William E. Roscoe. 2005. Report on Placer gold properties in the Tuul Valley, Zaamar Goldfield, Mongolia. Ulaanbaatar: Khan Resource.

Knight, Sam. 2007. Ninja miners carve out a new nation. TimesOnline, July 21. http:// find.galegroup.com/ttda/infomark.do?\&source $=$ gale\&prodId $=$ TTDA\&user GroupName $=$ cambuni\&tabID $=$ T003\&docPage $=$ article\&search Type $=$ Basic SearchForm\&docId $=$ IF503591150\&type $=$ multipage \&contentSet $=$ LTO \&version $=1.0$.

Kommisiia (Kommisiia dlia sobraniia i razrabotki svedenii o sibirskoi zolotopromyshlennosti i dlia sostavleniia programmy izsledovaniia zolotonosnykh raionov), ed. 1901. Perechen' zolotopromyshlennykh raionov Sibiri i opisanie priiskovykh dorog. St. Petersburg: Tipografiia L. Smol'ianinova. [SU]

Kormazov, V. A. 1927. "Zolotopromyshlennost" v Kheiluntszianskoi provintsii. Vestnik Man'chzhurii 3:41-46. [SU]

Kuttner, Robert. 2017. The man from Red Vienna (Karl Polanyi: A Life on the Left by Gareth Dale, Columbia University Press). New York Review of Books, December 21. https://www.nybooks.com/articles/2017/12/21/karl-polanyi -man-from-red-vienna/. [NB]

Laiz, Alvaro, and David Rengel. 2014. The ninja miners of Mongolia: a look at the harsh life of the "ninja" miners of Mongolia. Diplomat, April 21. http:// thediplomat.com/2014/04/the-ninja-miners-of-mongolia/.

Larin, Aleksandr. 2009. Kitaiskie migranty v Rossii: Istoriia $i$ sovremennost. Moscow: Vostochnaia kniga. [SU] 
Lattimore, Owen. 1934. The Mongols of Manchuria. New York: Day. 1951. Inner Asian frontiers of China. Irvington-on-Hudson, NY: Capitol; New York: American Geographical Society. [NB]

Li, Tania M. 2007. The will to improve: governmentality, development and the practice of politics. Durham, NC: Duke University Press. [ET]

. 2011. Rendering society technical: government through community and the ethnographic turn at the World Bank in Indonesia. In Adventure in Aidland: the anthropology of professionals in international development. David Mosse, ed. Pp. 57-80. Oxford: Berghahn. [ET]

Locke, John. 2007 (1689). Two treatises of government. Minneapolis: Filiquarian. Martinez Alier, Joan. 2002. The environmentalism of the poor. London: Elgar. Millar, Kathleen. 2014. The precarious present: wageless labor and disrupted life in Rio de Janeiro, Brazil. Cultural Anthropology 29(1):32-53.

Mongolian Statistical Office. 2012. Bichil uurkhai erkhlegchdiin sudalgaani negdsen tailan. [Research report of small-scale miners]. Ulaanbaatar: Mongolian Statistical Office.

Mosse, David. 2001. "People's knowledge," participation and patronage: operations and representations in rural development. In Participation - the new tyranny? Bill Cooke and Uma Kothari, eds. Pp. 16-35. London: Zed. [ET]

- 2005. Cultivating development: an ethnography of aid policy and practice. London: Pluto.

Munkherdene, G. 2011. Burzaij baina uu? ninja nar, tednii zokhion baiguulalt khiigeed ami zuulga [Are you getting loaded? ninjas, their organization and livelihood]. Ulaanbaatar: Meeting Point.

Munkh-Erdene, Lhamsuren. 2011. Mongolia's post-socialist transition: a great neoliberal transformation. In Mongolians after socialism: politics, economy religion. B. Knauft and R. Taupier, eds. Pp. 61-66. Ulaanbaatar: Admon.

Murray, William. 2003. Informal gold mining and national development: the case of Mongolia. International Development Planning Review 25(2):111-128. [BD]

Murray, William, and Robin Grayson. 2003. Overview of artisanal mining activity in Mongolia. Washington, DC: World Bank, IFC Mining Department.

Nasanbaljir, J. 1964. Ar mongoloos manj chin ulsad zalguulj baisan alba 16911911 [Tributes of Mongolia to the Manchu Qing 1691-1911]. Ulaanbaatar: Ulsyn hevleliin gazar. [BD]

National Statistical Office of Mongolia. 1999. Mongol Ulsyn Statistikiin Emkhetgel 1998 [Mongolian statistical yearbook 1998]. Ulaanbaatar: National Statistical Office of Mongolia.

Navch, T., T. Bolormaa, B. Enkhtsetseg, D. Khurelmaa, and B. Munkhjargal. 2006. Informal gold mining in Mongolia: a baseline survey report covering Bornuur and Zaamar Sums, Tuv Aimag. Bangkok: International Labor Office. http://www.ilo.org/wcmsp5/groups/public/-asia/-ro-bangkok/documents /publication/wcms_bk_pb_123_en.pdf.

Nolan, Peter. 1995. China's rise, Russia's fall: politics, economics and planning in the transition from Stalinism. London: Macmillan.

Obzor Zabaikal'skoi oblasti za 1910 god [Survey/overview of the Trans-Baikal region in 1910]. Chita, 1911. [SU]

Ochirbat, P. 1996. Tengeriin tsag [The heavenly hour]. Ulaanbaatar: Nomin Impex.

Odgerel, T., A. Enkhtur, G. Agar-Erdene, and T. Enkhtsetseg. 2012. Mongol dakhi bichil uurkhai ba hunii erkh 2012 [Artisanal mining and human rights in Mongolia 2012]. Ulaanbaatar: National Human Rights Commission of Mon golia. http://mn-nhrc.org/index.php?newsid $=5288$. [BI]

Ostrom, E. 1990. Governing the commons: the evolution of institutions for collective action. Cambridge: Cambridge University Press.

Pedersen, Morten A. 2014. Islands of nature. Insular objects and frozen spirits in northern Mongolia. In Anthropology and nature. K. Hastrup, ed. Pp. $96-$ 107. New York: Routledge. [GD]

Plueckhahn, Rebekah. Forthcoming. Shaping urban futures in Ulaanbaatar. London: UCL. [BD]

Rossabi, Morris. 2005. Modern Mongolia: from khans to commissars to capitalists. Berkeley: University of California Press.

SDC (Swiss Agency for Development and Cooperation). 2012a. SDC experiences with formalization and responsible environmental practices in arti sanal and small-scale gold mining in Latin America and Asia (Mongolia). Bern: Swiss Agency for Development and Cooperation. [ET]

2012b. Sustainable artisanal mining project. Ulaanbaatar: Swiss Agency for Development and Cooperation.
2015. Swiss Agency for Development and Cooperation in Mongolia annual report 2014. Ulaanbaatar: Gamma Photo Agency.

. 2016. Professionalising artisanal mining in Mongolia: a sustainable artisanal mining project success story. Bern: Swiss Agency for Development and Cooperation. http://www.eisourcebook.org/cms/April\%202016/Mongolia ,\%20Professionalizing\%20Artisanal\%20Mining.pdf.

Shimamura, Ippei. 2014. Ancestral spirits love mining sites: shamanic activities around a copper-gold mining site in Mongolia. Inner Asia 16(2):393-408.

Siegel, Shefa, and Marcello M. Veiga. 2010. The myth of alternative livelihoods: artisanal mining, gold and poverty. International Journal of Environment and Pollution 41:3-4.

Singo, Pascale. 2012. Mongolia case study: analysis of formalization approaches in the artisanal and small-scale gold mining sector based on experiences in Ecuador, Mongolia, Peru, Tanzania and Uganda. Nairobi: United Nations Environment Program. [ET]

Singo, Patience. n.d. Supporting artisanal miners in Mongolia: SDC's experiences and lessons learnt. Swiss Cooperation Office Mongolia. https://slideplayer.com /slide/10098346/.

Sneath, David. 2003. Land use, the environment and development in postsocialist Mongolia. Oxford Development Studies 31(4):441-459.

. 2004. Proprietary regimes and sociotechnical systems: rights over land in Mongolia's "age of the market." In Property in question: value transformation in the global economy. K. Verdery and C. Humphrey, eds. Pp. 161-182. Oxford: Berg.

. 2010. Political mobilization and the construction of collective identity in Mongolia. Central Asia Survey 29(3):251-267.

. 2014. Nationalising civilisational resources: sacred mountains and cosmopolitical ritual in Mongolia. Asian Ethnicity 15(4):458-472.

Sodbaatar, Y. 2013. Mongolyn Uul Uurkhain Tüüh [The history of mining in Mongolia]. Ulaanbaatar: Mönhiin Üseg. [BD]

Statistical Office of Mongolia. 1993. Mongolyn Ediin Zasag, Niigem 1992 [Mongolian economy and society in 1992]. Ulaanbaatar: J. L. D. Gurval.

Thomas, Constance, and K. Ganbaatar. 2006. Informal gold mining: foreword. In Informal gold mining in Mongolia: a baseline survey report covering Bornuur and Zaamar Soums, Tuv Aimag. T. Navch, T. Bolormaa, B. Enkhtsetseg, D. Khurelmaa, and B. Munkhjargal, eds. Bangkok: International Labor Office.

Torgashev, B. P. 1927. Zoloto v Man'chzhurii. Vestnik Man'chzhurii 8:47-52. [SU]

Tsetsentsolmon, B. 2014. The "gong beat" against the "uncultured": contested notions of culture and civilization in Mongolia. Asian Ethnicity 15(4):422-438 Tsing, Anna. 2015. Salvage accumulation, or the structural effects of capitalist generativity. Cultural Anthropology, March 30. https://culanth.org /fieldsights/656-salvage-accumulation-or-the-structural-effects-of-capitalist -generativity.

Tuya, S., and B. Battomor. 2012. Uul uurhai mongol orond [Mining in Mongolia]. Ulaanbaatar: Jikom. [BD]

Ulziibayar, B., and B. Tsetsenbileg. 2010. Minerals laws of Mongolia (19102010). Ulaanbaatar: MBS Law Firm. [BD]

UNEP (United Nations Environment Program). 2012. Analysis of formalization approaches in the artisanal and small-scale gold mining sector based on experiences in Ecuador, Mongolia, Peru, Tanzania and Uganda: Mongolia case study. https://wedocs.unep.org/bitstream/handle/20.500.11822/11630/Case_Studies _Mongolia_June_2012.pdf?amp\%3BisAllowedp\&sequencep1.

United Nations Systems in Mongolia. 1999. Annual report 1998. http://www .un-mongolia.mn/publications/anrep98.pdf.

Verdery, Katherine. 2003. The vanishing hectare: property and value in postsocialist Transylvania. Ithaca, NY: Cornell University Press.

Watts, Michael. 2004. Resource curse? governmentality, oil and power in the Niger Delta, Nigeria. Geopolitics 9(1):50-80. [BD]

World Bank. 1994. Mongolia: country economic memorandum: priorities in macroeconomic management. Report 13612-MOG. Washington, DC: World Bank, Country Operations Division, China and Mongolia Department, Asia and Pacific Regional Office.

2006. Mongolia: a review of environmental and social impacts in the mining sector. Washington, DC: World Bank.

Zatsepine, Victor. 2017. Beyond the Amur: frontier encounters between China and Russia, 1850-1930. Vancouver: UBC Press. [SU] 